\title{
월드프렌즈코리아(WFK) 중장기 전략 수립을 위한 타국 해외봉사단 성과지표조사
}

목 차

I. 연구 배경 및 소개

II. 미국 Peace Corps

1. 성과 관리 개요

2. 성과 측정을 위한 목표와 지표

3. 증거 기반 성과 평가를 위한 데이터 수집 및 관리 전략

III. 영국 해외시민봉사단(ICS)

1. 개요

2. 성과 논리 모형 및 지표와 문항

IV. 호주 국제개발봉사프로그램(AVID)

1. 개요

2. 수원국 기관의 역량 개발에 미치는 영향 측정

3. 평가 문항

V. 한국 월드프렌즈코리아(WFK)

1. 개요

2. 성과모형 및 지표

VI. 종합 분석 및 결론

참고 문헌 


\section{요 약}

현재 전 세계적으로 해외 봉사 성과측정을 위한 지표나 데이터 체계에 통일성과 기준 이 부재한 상황이다. 본 연구는 해외 봉사 성과관리 체계와 지표 구축에 선진적 노력을 기울이고 있는 미국, 영국, 호주의 사례를 분석해 월드프렌즈(WFK) 사업 성과지표 수립을 위한 시사점을 도출했다. 미국 피스코는 3 대 전략목표에 따른 봉사 활동의 내용 과 세부 목표 그리고 세부 지표를 보유하고 있으며, 전 지표에 대한 근거와 측정산식, 데이터의 정확성과 완성도 또한 철저히 관리하고 있다. 변화이론에 초점을 둔 영국 해외시민봉사단(International Citizen Service, ICS) 사업의 성과 체계는 투입물부터 장기적 결과물 수준까지의 성과지표 pool을 보유하고 있고, 체계적인 데이터 수집 방법 과 전략을 보유하고 있다. 호주 국제개발봉사프로그램(Australian Volunteers for International Development, AVID) 사업의 성과 체계 역시 논리모형을 기반으로 하고 있으며, 만족도(satisfacton) 설문조사 형식의 평가 방식도 활용하고 있다. WFK 중장기 성과 관리에 용이한 지표와 산식의 수립을 위해서는 선진 사례를 참고해 WFK 사업에 벤치마킹이 가능한 지표 pool 선정과 측정산식 검토에서부터 지표와 산식을 WFK 사업에 적용 및 확산까지의 단계적 작업이 견고하고 논리적으로 수행되어야 한다. 


\section{I. 연구 배경 및 소개}

세계에서 처음으로 해외봉사단 파견 기관이 1950년대에 호주에서 공식 설립된 이후, 2000년 대부터 해외 봉사 성과측정에 대한 관심이 높아지기 시작했다. 그러나 현재 성과측정을 위한 지표나 데이터 수집 체계가 구체적으로 수립되어 있는 해외봉사단은 드물며, 봉사단마다 우선시하 는 성과가 다르기 때문에 전 세계 각지의 해외봉사단 간의 성과 체계와 측정에 있어서 일관적이지 않고 또 기준이 부재한 것도 사실이다.1) 따라서 본 연구는 2016년을 기준으로 해외 봉사의 성과 관리 체계 및 구체적인 지표가 구축되어 있는 선진국 사례를 분석해, 월드프렌즈코리아(World Friends Korea, 이하 WFK)를 위한 시사점 도출을 목표로 한다. 특히 구체적인 성과 측정 체계의 수립에 있어 선진적 노력을 기울이고 있는 미국, 영국, 호주 사례를 집중적으로 조명하겠다.

최근 미국의 평화봉사단(Peace Corps, 이하 피스코), 영국의 해외시민봉사단(International Citizen Service, 이하 ICS), 호주의 국제개발봉사프로그램(Australian Volunteers for International Development, 이하 AVID)의 성과지표에 대한 몇 가지 국내 선행연구가 있었다 (<표 $1>$ 참고).

〈표 1〉타국 해외봉사단 성과 관리 시례에 관한 국내 선행연구(시례 국가별) 정리 및 한계점

\begin{tabular}{|c|c|c|c|}
\hline 사례 & 주요 주제·내용 & 연구 수행자 · 챕터 & 한계점 \\
\hline \multirow{2}{*}{$\begin{array}{l}\text { 미국 Peace } \\
\text { Corps }\end{array}$} & $\begin{array}{l}\text { 목표 및 세부 목표 연계, 방법론 } \\
\text { 정리 }\end{array}$ & $\begin{array}{l}\text { 이태주 외 (2016) } \\
\quad \text { pp.22 3 }\end{array}$ & $\begin{array}{l}\text { 평가 모형 및 세부 지표를 다루지 않음. 보완 } \\
\text { 필요 }\end{array}$ \\
\hline & 가치사슬 분석 & $\begin{array}{l}\text { 주성수 외 (2016) } \\
\text { pp.51 120 }\end{array}$ & $\begin{array}{l}\text { 2013년도 자료를 주로 조사함. 성과지표 세 } \\
\text { 부 내용 재구성 및 보완 필요 }\end{array}$ \\
\hline \multirow{3}{*}{$\begin{array}{l}\text { 영국 VSO . } \\
\qquad \text { ICS }\end{array}$} & ICS 평가 모형 및 방법론 정리 & $\begin{array}{l}\text { 이태주 외 (2016) } \\
\text { pp.24 5 }\end{array}$ & 세부지표 내용 보완 필요 \\
\hline & VSO 가치사슬 분석 & $\begin{array}{l}\text { 주성수 외 (2016) } \\
\text { pp.121 52 }\end{array}$ & $\begin{array}{l}\text { 성과 모형 - 틀을 다루지 않음. 성과지표 세부 } \\
\text { 내용 재구성 및 보완 필요 }\end{array}$ \\
\hline & $\begin{array}{l}\text { VSO 성과 관리 체계 및 ICS 평가 } \\
\text { 모형과 방법론 정리 }\end{array}$ & $\begin{array}{l}\text { 홍문숙 외 (2016) } \\
\text { pp.35 40 }\end{array}$ & 세부지표 내용 보완 필요 \\
\hline \multirow{3}{*}{ 호주 AVID } & 평가 모형 및 방법론 정리 & $\begin{array}{l}\text { 이태주 외 (2016) } \\
\text { pp.25 7 }\end{array}$ & 세부지표 내용 보완 필요 \\
\hline & 가치사슬 분석 & $\begin{array}{l}\text { 주성수 외 (2016) } \\
\text { pp.153 78 }\end{array}$ & 성과지표 세부 내용 보완 필요 \\
\hline & 성과 모형 및 방법론 정리 & $\begin{array}{l}\text { 홍문숙 외 (2016) } \\
\text { pp.40 3 }\end{array}$ & 세부지표 내용 보완 필요 \\
\hline
\end{tabular}

출처: 이태주 외 (2016), 주성수 외 (2016), 홍문숙 외 (2016) 내용을 저자가 재구성

1) 동 사항에 대한 더 자세한 내용은 구영은 외(2016) 및 구영은-최경화(2017)를 참고하면 된다. 2편의 선행연구가 해외봉사단의 성과 요소와 성과 측정 동향을 분석하는 것이었다면, 본 연구는 해외봉사단의 성과지표에 대한 구체적 해외 사례(미국, 영국, 호주)에 대해 조사를 한 것이다. 
위 <표 $1>$ 에서 명시한 선행연구와는 달리 본 연구는 타국 성과 관리·지표 사례에 관한 국내 선행연구의 한계로 지적된 사항을 보완하는 차원에서, 성과의 세부지표에 초점을 맞출 것이라는 점에서 차별화를 시도했다. 국내 선행연구에서 이미 다룬 바 있는 타국 봉사단의 운영 구조나 현황 등에 대한 전반적 설명은 생략하기로 한다. 


\section{II. 미국 Peace Corps}

\section{1. 성과 관리 개요}

피스코는 봉사단원들의 활동이 피스코의 목표와 전략적 계획에 일치하도록 성과 관리를 연중 시행하고 있다. 피스코는 아래 <표 2>에서 명시하는 성과측정 체계·방법을 채택하고 있으며, 이를 통해 얻은 증거와 자료를 바탕으로 프로그램 정책과 예산에 대한 의사 결정을 거쳐 피스코 의 성과를 제고하는 방법을 강구하고 있다(Peace Corps, 2016a: 31).

〈표 2〉 피스코 성과관리 개요 요약

\begin{tabular}{|c|c|}
\hline 방법 & 설명 \\
\hline $\begin{array}{l}\text { 통합적 계획·예산 체계 } \\
\text { (Integrated Planning and } \\
\text { Budget System, IPBS) }\end{array}$ & $\begin{array}{l}\text { 통합 계획 · 예산 체계(Planning and Budget System, 이하 IPBS)를 통해 피스코 } \\
\text { 본부와 해외 사무소는 활동 전략과 운영 계획을 피스코의 전략목표와 일치시킴. } \\
\text { IPBS의 계획은 피스코의 예산 배정 단계에서 기획되며, IPBS를 통해 성과 } \\
\text { (performance)와 예산 프로세스 간의 연계를 견고히 함으로써 프로그램, 정책, 예산 } \\
\text { 에 대해 적절한 의사 결정을 지원함. }\end{array}$ \\
\hline $\begin{array}{c}\text { 국가 포트폴리오 검토 } \\
\text { (Country Portfolio Review) }\end{array}$ & $\begin{array}{l}\text { 매년 국가별로 예비 단원과 활동 중인 단원들에 대한 통합적 검토를 수행함. 국가 } \\
\text { 포트폴리오 검토(country portfolio review)를 통해 새로운 수원국 및 활동이 종료된 } \\
\text { 국가에 관한 의사 결정, 봉사단원의 배치와 관련된 의사 결정에 있어 유용한 정보를 } \\
\text { 획득할 수 있음. }\end{array}$ \\
\hline $\begin{array}{l}\text { 분기별 전략계획 성과 } \\
\text { 검토(Quarterly Strategic } \\
\text { Plan Performance Reviews) }\end{array}$ & $\begin{array}{l}\text { 피스코 주요 임원들은 분기별로 성과자료(performance data)를 검토해 우수 사례 } \\
\text { 를 공유하고 또 성과 목표를 달성하기 위한 전략을 개발함. 분기별 회의에서 주요 } \\
\text { 성과(performance spotlight)를 발견·확인해 프로그램, 정책, 예산 결정에 반영함. }\end{array}$ \\
\hline $\begin{array}{c}\text { 연간 전략 검토 } \\
\text { (Annual Strategic Review) }\end{array}$ & $\begin{array}{l}\text { 전략계획에 명시된 전략목표 달성을 검토하기 위해 연간전략 검토(annual strategic } \\
\text { review)를 매년 실시함. 동 검토는 본부·사무소에서 제출한 통합 계획 - 예산 체계 } \\
\text { (IPBS)에 근거하며, 피스코의 고위 임원들도 검토에 참여함으로써 연간 계획 - 예산 } \\
\text { 편성, 연간 성과향상 분야 선정, 잠재적 평가 주제 선정 등에 관한 정보를 공유해 } \\
\text { 피스코 활동의 효과성에 대한 이해를 증진시킴. }\end{array}$ \\
\hline
\end{tabular}

출처: Peace Corps, (2016a) p.31 내용을 저자가 재구성 


\section{2. 성과 측정을 위한 목표와 지표}

\section{1) 전략적 목표 및 지표}

피스코법(The Peace Corps Act, 1961)은 피스코의 미션인 세계 평화와 우정 증진에 기여 하는 3개의 핵심 목표를 명시하고 있으며(Peace Corps, 2016a: 4), 동 목표는 현재까지도 피스코 성과 전략의 핵심 목표로 이어지고 있다(<표 $3>$ 참고).

\section{〈표 3〉 피스코의 3가지 전략목표(Strategic Goal)}

\begin{tabular}{|c|c|}
\hline 전략목표 & 설명 \\
\hline $\begin{array}{c}\text { 현지 역량 구축 } \\
\text { (Building Local Capacity) }\end{array}$ & $\begin{array}{l}\text { - 수원국의 지역사회와 개인의 역량을 강화함으로써 지역개발을 증진 } \\
\text { - 농업, 지역 경제, 교육, 환경, 보건, 청소년 분야 프로젝트에 참여해 지역 파트 } \\
\text { 너 기관과 개인을 대상으로 훈련을 실시 } \\
\text { · 역량 구축 활동으로 지역 기관 및 개인의 개발문제 해결능력을 강화해 지역의 } \\
\text { 생활 개선에 기여 }\end{array}$ \\
\hline $\begin{array}{l}\text { 미국을 세계와 공유 } \\
\text { (Sharing America with the } \\
\text { World) }\end{array}$ & $\begin{array}{l}\text { - 봉사단원이 수원국의 지역사회에서 거주하며 활동함으로써 미국인에 대한 } \\
\text { 이해 증진 } \\
\text { - 미국인에 대한 지역 주민들의 오해를 불식시키고 이해를 증진 } \\
\text { - 봉사단원과 지역 주민 간의 긴밀한 관계를 유지해 지역사회의 강점과 문제점 } \\
\text { 을 배우고, 지역 협력 기관과의 신뢰를 구축하며 프로젝트 활동을 강화 }\end{array}$ \\
\hline $\begin{array}{l}\text { 미국에 세계를 전파 } \\
\text { (Bringing the World Back } \\
\text { Home) }\end{array}$ & $\begin{array}{l}\text { - 피스코 경험을 공유해 미국인들의 타 문화와 글로벌 이슈에 대한 이해와 지식 } \\
\text { 증진 } \\
\text { · 해외봉사단원이 국내(미국)에서도 봉사를 지속하도록 지원 }\end{array}$ \\
\hline
\end{tabular}

출처: Peace Corps, (2016a) p.6 내용을 저자가 재구성

피스코 차원의 성과 평가는 위 <표 3 >의 3 대 전략목표를 주축으로 26 개의 구체적인 목표에 대한 성과를 측정함으로써 이루어진다. 아래 <표 $4>$ 는 3 대 전략목표, 11 개 세부목표, 26 개 성과목표 간 연계를 보여 준다. 
〈표 4〉 피스코 3 대 전략목표, 11 개 세부목표, 26 개 성과목표 간 연계

\begin{tabular}{|c|c|c|c|c|}
\hline \multirow[b]{2}{*}{$\begin{array}{l}\text { 11개 전략 세부목표 } \\
\text { (Strategic Objectives) }\end{array}$} & \multirow[b]{2}{*}{$\begin{array}{c}\text { 26개 성과목표 } \\
\text { (Performance Goals) }\end{array}$} & \multicolumn{3}{|c|}{ 전략목표 } \\
\hline & & $\begin{array}{l}\text { 현지 } \\
\text { 역량 } \\
\text { 구축 }\end{array}$ & $\begin{array}{l}\text { 미국을 } \\
\text { 세계와 } \\
\text { 공유 }\end{array}$ & $\begin{array}{l}\text { 미국에 } \\
\text { 세계를 } \\
\text { 전파 }\end{array}$ \\
\hline \multirow{2}{*}{ 1. 봉사단원 웰빙 } & 안전 · 안전 관리 만족도 향상 & \multirow{2}{*}{$\bullet$} & \multirow{2}{*}{$\bullet$} & \multirow{2}{*}{$\bullet$} \\
\hline & 의료 - 정신건강 지원 불만족 감소 & & & \\
\hline \multirow{4}{*}{ 2. 봉사활동 기회 제공 } & 봉사단원 수요 충족 & \multirow{4}{*}{$\bullet$} & \multirow{4}{*}{$\bullet$} & \multirow{4}{*}{$\bullet$} \\
\hline & 봉사활동 참여 인원 증대 & & & \\
\hline & 봉사활동 지원자 수 증대 & & & \\
\hline & 봉사활동 지원 기간 감축 & & & \\
\hline \multirow{3}{*}{ 3. 개발에 대한 영향 } & 지역기반 개발성과 증대 & \multirow{3}{*}{$\bullet$} & \multirow{3}{*}{$\bullet$} & \\
\hline & 지역 역량강화 & & & \\
\hline & 봉사단원에 대한 피드백 & & & \\
\hline \multirow{2}{*}{ 4. 범문화적 } & 미국인에 대한 이해 증대 & \multirow{2}{*}{$\bullet$} & \multirow{2}{*}{$\bullet$} & \multirow{2}{*}{$\bullet$} \\
\hline & 문화교류 증대 & & & \\
\hline \multirow{2}{*}{ 5. 사후 관리 } & 귀국 봉사단원 진로 지원 & & & \multirow{2}{*}{$\bullet$} \\
\hline & 귀국 봉사단원 지속적 참여 증대 & & & \\
\hline \multirow{2}{*}{ 6. 다양성과 포용성 } & 봉사활동 지원자 다양성 & \multirow{2}{*}{$\bullet$} & \multirow{2}{*}{$\bullet$} & \multirow{2}{*}{ • } \\
\hline & 통합적이며 열린 분위기 조성 & & & \\
\hline \multirow{2}{*}{ 7. 현지 환경 개발 } & 파견 지역 발굴·준비 개선 & \multirow{2}{*}{$\bullet$} & \multirow{2}{*}{$\bullet$} & \\
\hline & 현지 협력자 선택·준비 개선 & & & \\
\hline \multirow{2}{*}{ 8. 훈련 강화 } & 언어 습득력 향상 & \multirow{2}{*}{$\bullet$} & \multirow{2}{*}{$\bullet$} & \\
\hline & 기술교육 효과성 증대 & & & \\
\hline \multirow{2}{*}{ 9. 높은 성과 - 학습 추구 } & 기관 직원 훈련 & \multirow{2}{*}{$\bullet$} & \multirow{2}{*}{$\bullet$} & - \\
\hline & 직원 재임 기간 확대 & & & - \\
\hline 10 글ㄹㅂㅓㅓ 여계서 & 통합기술 플랫폼 개발 & 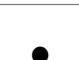 & 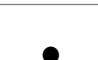 & e \\
\hline 10. 를도밀 연계성 & 지식공유 촉진 & $\boldsymbol{\theta}$ & - & - \\
\hline & 기초조사 수행 & & & \\
\hline 11. 결과 측정 & 증거기반 의사결정 증대 & $\bullet$ & $\bullet$ & $\bullet$ \\
\hline & 증거기반 혁신 촉진 & & & \\
\hline
\end{tabular}

출처: Peace Corps (2016a) p.6 내용을 저자가 재구성

아래 <표 $5>$ 는 위 <표 $4>$ 에서 명시한 11 개의 세부 목표를 달성하기 위한 전략, 활동 내용, 성과 목표, 정량적 지표를 자세히 명시하고 있다. 
〈표 5〉 피스코의 봉사활동 세부 목표, 세부 활동 및 성과지표의 정의

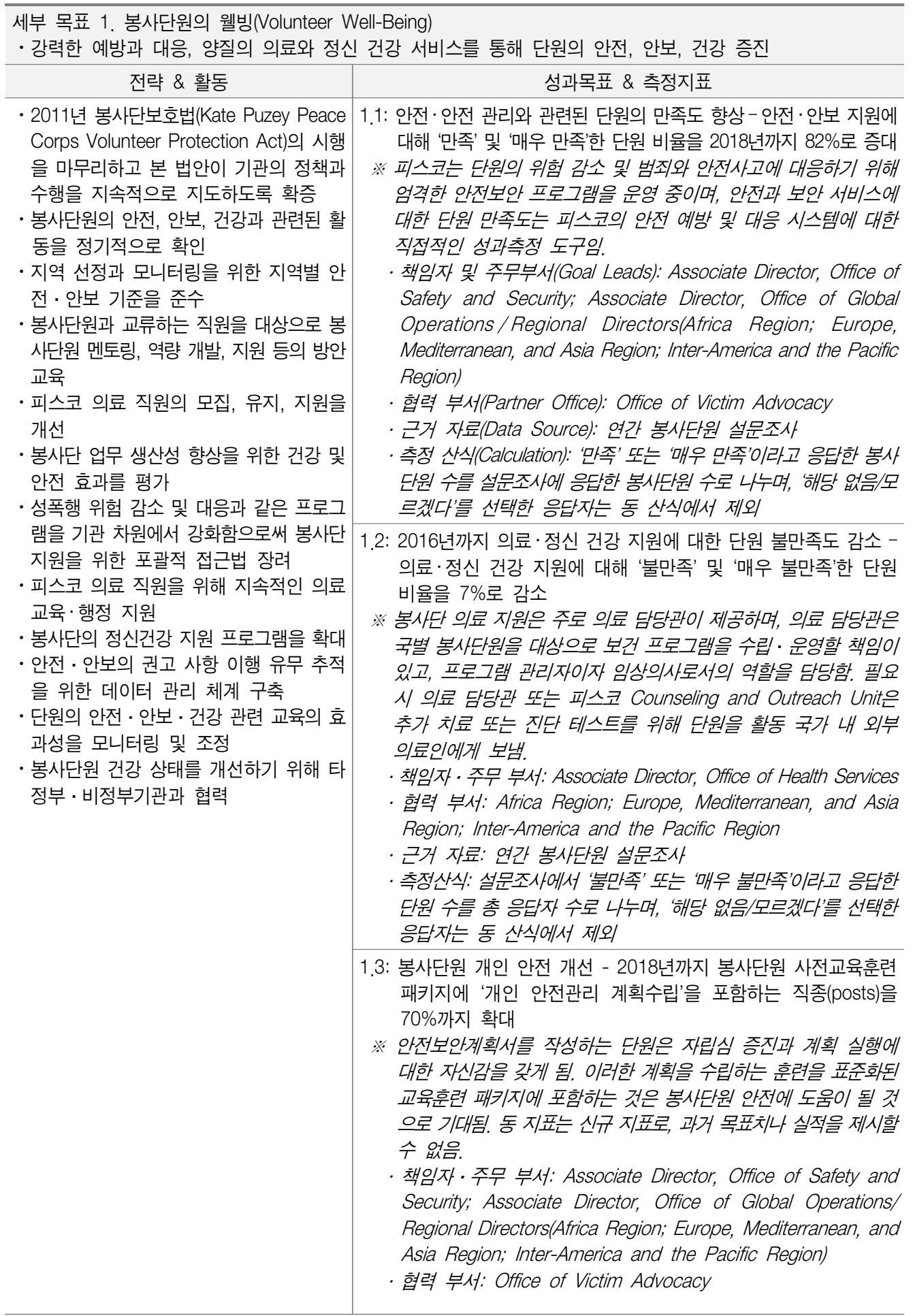


· 근거 자료: 피스코 행정 기록

· 측정산식: 사전교육을 제공하는 직종 중에서 표준화된 사전교육훈 련의 일환으로 개인 안전관리 계획 수립을 도입한 비율

세부 목표 2. 봉사활동 기회 제공(Service Opportunity of Choice)

- 예비 봉사단원과 접촉 등을 통해 지원 절차를 간소화시켜, 피스코가 바로 해외 봉사에 관심이 있는 재능 있는 미국인들이 선택하는 최고의 기관이라는 위상을 제고

\section{전략 \& 활동}

- 투명성 제고 - 지원자의 선호도 향상을 위 2.1: 단원 수요 충족 - 해외 사무소의 요청에 따라 매년 봉사단원의 해 단원이 특정 국가, 분야, 출발 시기를 선택하도록 기존 사업 과정 및 지원 플랫 폼 조정

- 매년 파견되는 봉사단 요청을 위해 사전 대기자 시스템 구축

- 지원자 모집 - 평가를 위한 분기별 지원 시스템을 구축하고, 이를 통해 경쟁력 있 는 봉사단원 선발

- 잠재 봉사단 핵심 그룹(18 26세) 및 향후 그룹(15 17세)과 이들에 대한 영향력 행 사 그룹(가족 및 친구)의 목표, 선호도, 주 요 동기, 방해 요인을 파악하기 위해 시장 조사 진행

- 봉사단에 대한 인식 개선을 위해 공공 외 교 및 마케팅 관련 캠페인 실시

- 잠재 봉사단을 위한 의사소통 서비스 개 선(피스코 웹사이트를 재구성하고, 모바 일 플랫폼을 추가하는 콘텐츠 개발 등)

- 모집 전략을 적극 활용해 지원자 채용

- 해외 사무소에서 봉사단 모집에 활용하는 '지역 업무 시스템'을 '초점 - 훈련 강화 프 로그램'과 연계해 재구성

- 전략적 중개 기관, 대학교, 공공 - 민간 파 트너십을 활용해 연간 봉사단 인원 및 시 범 봉사활동 프로그램을 증가

- 지원, 평가, 배치 절차를 향상하기 위한 개혁의 효과성을 평가 파견 비율 $100 \%$ 달성

※ 합격과 출국 사이에 소모되는 기간은 지원자의 의료, 법적 절차, 가정, 학업 또는 직장 계획의 변화 등 여러 원인으로 예측하기 어려움. 피스코는 해외 수요에 대응하기 위해 합격과 출국 사이에 소모되는 기간을 지속적으로 줄여 나갈 것임.

- 책임자. 주무 부서: Associate Director, Office of Volunteer Recruitment and Selection; Associate Director, Office of Global Operations/Regional Directors (Africa Region; Europe, Mediterranean, and Asia Region; Inter-America and the Pacific Region)

· 협력 부서: Office of Health Services

. 근거 자료: 피스코 데이터베이스(DOVE/PCVDBMS)

· 측정산식: 봉사단원 요청 숫자에서 실제 봉사활동을 시작한 교육생 비율

2.2: 활동 참여 단원 증대 - 파견 봉사단원을 연간 10,000 명으로 증대 ※ 피스코법에 프로그램과 재정 상황을 고려해 봉사단원을 최소 10,000 명 유지하는 것은 미국의 정책이며, 평화봉사단의 목적임 을 명시함. 지속적인 자금 조달이 가능할 경우, 더 큰 규모의 봉사 단원을 파견하는 것이 더 많은 미국인에게 봉사할 수 있는 기회를 제공하는 것이며 또 이것은 피스코의 최우선 과제임.

- 책임자. 주무 부서: Associate Director, Office of Volunteer Recruitment and Selection; Associate Director, Office of Global Operations/Regional Directors/Africa Region; Europe, Mediterranean, and Asia Region;Inter-America and the Pacific Region)

· 협력 부서: Peace Corps Response

· 근거 자료: 피스코 데이터베이스(DOVE/PCVDBMS)

· 측정산식: 매 회계연도 9월 30일 기준, Response Volunteers(긴급 구호봉사단)을 포함한 봉사단원 및 교육생 수

2.3: 활동 지원자 증대 - 2018년까지 봉사활동 지원자 수 25,000 명으로 증대

※ 피스코 지원자 수를 확대하는 것은 봉사활동 기회(Service Opportunity of Choice)에 있어서 피스코 경쟁력을 나타내는 명확 한 지표임. 기관의 목표는 경쟁력 있고 우수한 자격을 갖춘 후보자 가 현장에 배치되도록 봉사단 수요에 많은 지원자를 확보하는 것 임.

· 책임자-주무 부서: Associate Director, Office of Volunteer Recruitment and Selection

- 협력 부서: Peace Corps Response; Office of Communications; Office of Strategic Partnerships

· 근거 자료: 피스코 데이터베이스(DOVE/PCVDBMS)
제 I 장

제II 장

포

커

제피장 
· 측정산식: 18세 이상 미국 시민이 기본 2년 및 단기 긴급구호 프로그램에 제출한 지원서(completed applications) 숫자

2.4: 지원 기간 감소 - 2016년까지 평균 준비 시간(지원부터 파견까지) 을 3개월 미만으로 감소시키고 2018년까지 동 수준을 유지

※ 2014년 봉사단 지원 프로세스 개선 이전까지 예비 지원자들은 다 른 봉사활동 지원보다 피스코 지원 프로세스가 훨씬 더 길다고 인식하고, 이것을 피스코 지원을 가장 방해하는 이유로 들었음.

- 책임자-주무 부서: Associate Director, Office of Volunteer Recruitment and Selection

· 근거 자료: 피스코 데이터베이스(DOVE P PCVDBMS)

· 측정산식: (1) 지원 완료 날짜의료기록 양식 및 소프트 스킬설문지 등 지원 패키지) 및 (2) 합격(Invitation to Serve) 날짜 사이에 평균 소요 개월

세부 목표 3. 개발에 영향(Development Impact)

- 효과적 기술적 개입과 전략적 파트너십을 통해 지역사회의 개인과 기관의 역량을 강화시켜 지역사회 기반의 개발을 강화

전략 \& 활동

- 지역사회의 욕구를 충족하도록 봉사단의 역량 강화를 위해 표준화된 기술훈련 시행 · 봉사활동이 지역사회의 개발 과제를 정확 히 다룰 수 있도록 사업 자문위원회에서 현지의 요구 사항을 주기적으로 모니터링 · 현지 파트너 및 지역사회의 역량을 강화 하고 봉사단원과 효과적 협력 관계를 구 축하기 위해 관련 교육 기회 증가

·현지 파트너 및 지역사회와 협력하기 위 해 봉사단 교육 개선

· 단원에게 기술교육·수단· 자원을 제공하 기 위해 기관의 전략적 파트너와 연계

- 직원과 봉사단원을 대상으로 모니터링과 평가(M\&E) 교육 실시

· 봉사단에게 제공되는 피드백의 빈도 및 질적 기준 개발

\section{성과목표 \& 측정지표}

3: 2018년까지 지역사회 기반의 개발 성과 증대 - 지역사회 기반의 개발 성과 사업 비율을 $90 \%$ 로 증대

※ 프로젝트는 파견 국가의 공공 이익을 달성하기 위해 정해진 기간 동안 여러 봉사단 세대에 걸쳐 진행함. 개별 프로젝트 계획은 지역 파트너와 함께 설계되고 실행되며, 프로젝트 프레임워크(논리 모 델)는 프로젝트의 목적· 목표·활동·성과지표를 설명함. 19 개 표 준분야지표(standard sector indicators)는 피스코에 의해 채택된| 가장 공통된 지표이며, 표준성과지표는 프로젝트 활동의 결과로 지식·기술·태도 - 행동 및 환경 변화에 대한 성과 지향적 평가임. - 책임자 - 주무 부서: Associate Director, Office of Global Operations/ Regional Directors(Africa Region;Europe, Mediterranean, and Asia Region; Inter-America and the Pacific Region)

- 협력 부서: Office of Overseas Programming and Training Support; Office of Global Health and HIV/AIDS; Office of Strategic Partnerships; Office of Strategic Information, Research, and Planning

· 근거 자료: 봉사단 보고 툴(tool)

- 측정산식: 19 개 표준분야지표의 하나 또는 그 이상의 지표를 포함 하는 프로젝트 중에서 아래 2가지 기준에 부합하는 프로젝트 비율 * 2가지 기준: (1) 프로젝트에 참여한 봉사단원 중 최소한 $25 \%$ 가 어더한 형태의 성과를 보고해야만 함, (2) 모든 봉사단원 성과의 합은 최소한 프로젝트 연간 목표의 $25 \%$ 가 되어야 함.

3.2: 지역 역량 강화 - 현지 주민의 역량 강화 사업 비율 증대(2018년까 지 역량 강화를 보고한 파트너 · 동료(coworker) 비율을 $90 \%$ 까지 확대)

※ 단원은 활동 전반에 걸쳐 지역사회 파트너와 함께 일하면서 지역 역량을 강화함. 파트너(동료)는 단원과 활동하면서 습득한 지식 및 기술에 대해 질문을 받음. 동 성과지표의 가설은 동료의 역량 강화 가 그들이 커뮤니티에서 측정 가능하고 또 지속 가능한 성과를 달성하는 데 기여할 수 있다는 것임.

- 책임자.주무 부서: Associate Director, Office of Global Operations/Regional Directors (Africa Region; Europe, 
Mediterranean, and Asia Region; Inter-America and the Pacific Region)

· 협력 부서: Office of Overseas Programming and Training Support; Office of Strategic Information, Research, and Planning

· 근거 자료: 글로벌 파트너(동료) 조사

· 측정산식: 무작위로 추출해 인터뷰에 응답한 파트너(동료) 중 역량 강화 또는 혁신을 보고한 비율

3.3: 피드백을 통한 개선 - 봉사단원 활동에 따른 피드백의 적시성과 질에 대한 만족도 제고(2018년까지 '만족' 또는 '매우 만족' 응답률 $68 \%$ 달성이 목표)

※ 단원은 지역 커뮤니티에서 생활하고 일하기 때문에 종종 피스코 직원들과 멀리 떨어져 있음. 봉사단원들은 자신의 활동에 대해 이 메일, 문자메시지, 전화, 봉사단 보고 툴(Volunteer Reporting Tool) 등을 통해 피스코 직원으로부터 시기적절하고, 높은 수준의 피드백 을 받아 도전 과제를 해결할 수 있음.

. 책임자 - 주무 부서: Associate Director, Office of Global Operations/Regional Directors/Africa Region; Europe, Mediterranean, and Asia Region; Inter-America and the Pacific Region)

· 협력 부서: Office of Overseas Programming and Training Support; Office of the Chief Information Officer

· 근거 자료: 연례(annual) 봉사단원 설문조사

· 측정산식: 해당 질문에 '만족' 또는 '매우 만족'이라고 응답한 봉사 단 비율이며, ‘해당 사항 없음모르겠음'이라고 응답한 데이터는 제외

세부 목표 4. 범문화적 이해(Cross-Cultural Understanding)

- 미국과 수원국 개인·지역사회 간 장기·지속적 관계 구축을 통해 타 문화에 대한 상호 이해 증진 전략 \& 활동 성과목표 \& 측정지표

- 단원과 현지 직원을 대상으로 타 문화 이 4.1: 미국인 관련 이해 증대 - 2016년까지 지역 주민들의 미국인 이해도 해를 위한 역량 강화 교육 및 시스템 개발 - 현지 활동 중 및 귀국 봉사단이 모두 소셜 미디어 등 최신 기술을 활용해 미국인과 수원국 주민 간의 의사소통 활성화

- 단원이 현지에서 겪는 문화적 차이에 잘 대처하도록 훈련 제공

· 상대방의 교육과정에 따른 요구 사항 관 련 정보에 강사의 접근성 증대 를 95\%로 증대, 2018년까지 봉사단원과 활동한 후 미국에 대해 더 이해하게 된 파트너(동료) 비율을 $95 \%$ 수준으로 유지 - 책임자-주무 부서: Associate Director, Office of Global Operations/Regional Directors/Africa Region; Europe, Mediterranean, and Asia Region; Inter-America and the Pacific Region)

·협력 부서: Office of Overseas Programming and Training Support; Office of Strategic Information, Research and Planning

· 근거 자료: 글로벌카운터파트조사

· 측정산식: 무작위로 추출해 인터뷰에 응한 파트너(동료) 중 미국 또는 미국 사람에 대해 배우게 되었다고 응답한 비율

4.2: 문화교류 증대 - 2016년까지 미국인과 수원국 내 개인 - 지역사회 간 직접 교류를 가능케 한 단원 비율을 62\%로 증대, 2018년까지 $70 \%$ 수준으로 확대

- 책임자-주무 부서: Associate Director, Office of Global Operations; Director, Office of Overseas Programming and Training Support

· 협력 부서: Office of Third Goal and Returned Volunteer Services 
공하고, 귀국 단원의 참여를 독려해 독립

적인 봉사단 동호회 지원

세부 목표 6. 다양성과 포용성(Diversity and Inclusion)

- 다양한 배경의 직업을 가진 봉사단원을 적극적으로 모집 - 지원 · 유지하며, 협력 · 융통성 · 공정성을 증진시키는 포용적 문화 구축

$$
\text { 전략 \& 활동 }
$$$$
\text { 성과목표 \& 측정지표 }
$$

- 마케팅, 의사소통, 봉사활동 전략을 개발해 6.1: 봉사활동 지원자의 다양성 증대 - 2016년까지 소수 인종 및 집단 피스코의 봉사단원 및 직원의 인력풀을 다 양화

- 현지 지역사회와 협력해 소수집단을 지지 하고, 이들의 지원을 확대하기 위해 노력

- 봉사단원 서비스에 대한 경제적 장벽 파악 및 완화를 위해 노력

- 동성 커플이 피스코봉사단원에 함께 지원 할 수 있는 프로그램을 모니터링하고 지원 - 소수집단을 채용하는 역할을 수행할 수 있 는 귀국 봉사단원을 현지 직원이 추천할 수 있는 시스템 개발

- 소수집단을 모집하는 일에 귀국 봉사단원 이 참여

- 봉사단원 모집의 다양성을 위해 전략적 파 트너십 시행 및 지원

- 모집의 다양성 제고를 위해 지역별 모집 부 서에서 관련된 연간 계획을 수립 · 실시

- 중도 포기한 지원자에 대한 정보(인종, 성 별, 나이, 기타 요인 등)를 모니터링해 잠재 적 방해 요인 분석

- 직원의 고용 및 지원을 돕기 위해 직원 인 력 그룹을 지지

- 직원들의 인식 제고를 위한 다양한 훈련 제 공, 직원에 대한 다양한 차별과 희롱을 예 방할 수 있도록 이들의 권한을 강화

- 봉사활동 수행에 필요한 능력 이외의 다른 요인들로 인해 지원자가 제약을 받지 않도 록 봉사단원의 건강 상태를 비롯한 다양한 적격 기준의 검토 및 수정

· 기관 치원에서 다양성 거버넌스위원회(Diversity Governance Council)를 구축해 피스코 전 략 개선을 위한 피드백과 지침서를 제공, 제도적 이슈 및 다양성 - 포용성 관련 문제 를 파악 의 봉사활동 지원 비율을 35\%로 증대, 2018년까지 동일 수준 유지

- 책임자 - 주무 부서: Associate Director, Office of Volunteer Recruitment and Selection

· 협력 부서: Office of Communications; Office of Civil Rights and Diversity

· 근거 자료: 피스코 데이터베이스(DOVE P PCVDBMS)

· 측정산식: 전체 봉사단 지원 신청서 중 소수 인종 · 민족에 속한 봉사단 지원 신청서 비율이며, 관련 정보를 제공하지 않은 지원자 는 계산에서 제외

6.2: 포괄적이고 열린 기관 분위기 조성 - 기관 내 포용적이고 열린 조직 문화를 조성해 2016년까지 피스코 봉사단원과 미국 고용 또는 현지 직원 포용성에 '동의' 및 '매우 동의' 비율을 $90 \%$ 로 증 대, 2018년까지 동 수준 유지

- 책임자 - 주무 부서: Director, Office of Civil Rights and Diversity . 협력 부서: Office of Human Resource Management; Office of Overseas Programming and Training Support

· 근거 자료: 연례 봉사단원 설문조사(AVS), 미국 직접고용 국내외 직원 설문조사(Employee Viewpoint Survey, EVS), 현지직원 설문 조사(Host Country Staff Survey, HCSS)

- 측정산식: 각 설문조사(AVS, EVS, and HCSS) 응답자 중에서 '동 의' 또는 '매우 동의한다'를 선택한 응답자 비율이며, ‘해당 없음모 르겠음'을 선택한 응답자는 계산에서 제외

6.3: 지원자(합격자)의 다양성 개선 - 봉사단 합격 후에 지원 절차를 완료하는 소수자(minority)의 비율 증가

※ 2014년 7월에 지원 절차가 개정되었다. 지원 절차가 완료되는 데 1년 정도까지 소요될 수 있기 때문에 봉사단 지원자가 개정된 프로세스 안에서 모든 지원 절차를 완료하고, 이 데이터가 활용 가능할 때까지 목표치를 설정할 수 없다.

- 책임자 - 주무 부서: Associate Director, Office of Global Operations/Regional Directors (Africa Region; Europe, Mediterranean and Asia Region; Inter-America and the Pacific Region)

· 협력 부서: Office of Civil Rights and Diversity; Office of Volunteer Recruitment and Selection; Office of Overseas Programming and Training Support

· 근거 자료: 피스코 데이터베이스(DOVE/PCVDBMS)

· 측정산식: 2년간 봉사 프로그램 합격자 중에서 마지막 입출국 절차 를 완료하는 비율

세부 목표 7. 파견지 활동환경 개발(Site Development)

- 효과적 프로젝트 개발, 현지 활동환경 준비, 지역사회 파트너와의 성공적인 협력 등 통합적인 접근을 통해 봉사단원 의 성공을 유도하는 환경 조성 


\section{전략 \& 활동}

- 현지 특성을 살린 개발 기준 - 정책 - 과정 7 . 을 개발하고, 이를 전체적으로 적절하게 활용할 수 있도록 표준화 량 강화와 봉사단원 지원 요구를 충족시 키기 위해 직원과 봉사자 간의 비율 개선 · 수원국의 가정, 기관, 주요 파트너가 봉사 단원과 효과적으로 협력할 수 있도록 관련 교육 제공

- 지역사회의 요구 사항을 문서로 잘 정리 해 단원에게 분명하고 의미 있는 봉사활 동의 기회 제공

· 단원의 기술과 경험이 지역사회의 욕구를 충족하도록 지원

- 사업자문위원회(Project Advisory Committees)의 정기적인 모니터링을 통해 단원 이 지역사회의 요구 사항을 제대로 파악 하고 있는지 확인

- 모바일 기술을 개발해 현지의 효과적인 선택, 문서화, 준비 과정을 추적하고 기록
- 지역사회의 발전을 위한 현지 직원의 역

\section{성과목표 \& 측정지표}

7.1: 파견 지역(활동지, 주거지) 발굴 및 준비 개선 - 2018년까지 파견 지역 선정·준비에 대한 단원의 '만족' 및 '매우 만족' 비율을 $68 \%$ 로 증대

- 책임자 - 주무 부서: Associate Director, Office of Global Operations/Regional Directors/Africa Region; Europe, Mediterranean, and Asia Region; Inter-America and the Pacific Region)

· 협력 부서: Office of Health Services; Office of Safety and Security

· 근거 자료: 연례 봉사단원 설문조사

· 측정산식: 설문조사 응답자 중 '만족' 또는 '매우 만족'이라고 응답 한 단원 비율이며, '해당 없음모르겠음'이라고 응답한 경우 산식에 서 제외

7.2: 현지 협력자 선택 및 준비 개선 - 2018년까지 지역사회의 통합과 현지 파트너 업무 지원에 대한 단원의 '만족' 및 '매우 만족' 비율을 $61 \%$ 로 증대

·책임자 - 주무 부서: Associate Director, Office of Global Operations/Regional Directors/Africa Region; Europe, Mediterranean and Asia Region; Inter-America and the Pacific Region)

· 협력 부서: Office of Health Services; Office of Safety and Security

· 근거 자료: 연례 봉사단원 설문조사

· 측정산식: (1) 프로젝트 완수, (2) 커뮤니티 통합에 대한 파트네(동 료) 지원에 대해 '만족' 또는 '매우 만족'이라고 응답한 봉사단원 비율이며, '해당 없음모르겠음'이라고 응답한 경우 산식에서 제외

세부 목표 8. 단원 교육훈련(Train-Up)

- 활동 전 과정에서 지속적인 학습을 통해 효과적인 해외봉사단을 육성

$$
\text { 전략 \& 활동 }
$$

성과목표 \& 측정지표

· 초점 · 훈련(Focus-In · Train-Up) 전략을 통해 훈련 도구를 지속적으로 평가- 개선

- 사업 분야에 대한 봉사단원의 지속적 교 육은 봉사단원에게 자기 주도적 학습, 코 칭 및 멘토링, 개인 학습 계획을 장려

- 단원을 위한 최종 교육 목표를 수립하고, 사전 및 사후 훈련을 포함한 다양한 교육 과정을 통해 달성된 단원의 역량 평가

· 온라인 지식공유 플랫폼 활용해 훈련 · 언 어학습 과정 공유

· 공식 교육 자격증과 시험을 개발해 단원 이 제공한 훈련 내용과 성취된 전문성 및 역량 수준을 문서화

· 단원의 언어 시험 의무화 및 관리자 언어 시험을 시행

- 단원 교육 내용, 순서, 디자인에 대한 새로 운 접근법 시범 적용
8.1: 언어습득 능력 향상 - 활동 종료 전 언어 테스트에서 '고급' 및 '그 이상' 수준인 단원 비율을 2018년까지 70\%로 증대

※ 봉사단원 현지어 능력은 피스코가 인증하는 언어 시험관이 인터뷰 를 통해 평가하며, 외국어 인터뷰는 외국어교습위원회/American Council for Teaching Foreign Languages)의 가이드라인에 따라 초급, 중급, 고급, 최고급 4단계를 적용함.

- 책임자-주무 부서: Associate Director, Office of Global Operations/Regional Directors (Africa Region; Europe, Mediterranean and Asia Region; Inter-America and the Pacific Region); Director, Office of Overseas Programming and Training Support

협력 부서: Office of the Chief Information Officer · 근거 자료: 피스코 데이터베이스(VIDA)

· 측정산식: 활동 종료 시점에서 외국어능력테스트(인터뷰)를 받은 봉사단원 중 '고급' 또는 '최고급' 레벨을 통과한 단원 비율

8.2: 기술교육 효과 증대 - 훈련이 '효과적' 및 '매우 효과적' 이라고 응답한 단원 비율을 2018년까지 67\%로 증대

- 책임자-주무 부서: Associate Director, Office of Global Operations/Regional Directors (Africa Region; Europe, 
Mediterranean and Asia Region; Inter-America and the Pacific Region); Director, Office of Overseas Programming and Training Support

· 근거 자료: 연례 봉사단원 설문조사

· 측정산식: 응답자 중 '만족' 또는 '매우 만족'이라고 응답한 봉사단 원 비율이며, '해당 없음모르겠음'이라고 응답한 단원은 산식에서 제외

세부 목표 9. 높은 성과의 학습조직 형성(High-Performing Learning Organization)

- 피스코 직원의 전문성 개발을 위한 투자, 직원 유지 향상, 제도적 학습의 강화를 통해 고도의 성과를 내는 학습 조직(high-performing learning organization)을 양성

\section{전략 \& 활동}

- 국내외 피스코 직원을 위한 역량 강화 평가 프로그램 시행

- 비용면에서 효율적인 프로그램 개발을 위 해 교육과정 추적 자동화 시스템에 투자 - 기관 감독관을 위해 지도자급의 일관성 연속성 증진

- 직원의 개인 역량 개발을 위해 기관 내 감 독관과 협력

- 사무실 - 현장 기반 및 신입 직원의 오리 엔테이션을 비롯한 모든 직원에 대한 관 리 시스템 검토 및 표준화

- 기관 내 모든 직원을 대상으로 봉사단원과 의 협력 및 개인 경력 개발을 위한 효과적 인 전략 구축 코칭 프로그램 실행

- 운영의 지속성과 범위를 향상하기 위해 교차교육 장려

- 교육 예산의 효율적 편성을 위해 기관 전 체의 교육 관련 요구 사항과 비용 확인

- 현지 주요 직책의 공석 방지를 위해 효과 적인 인력풀 구축

- 현지 직원의 장기 공석을 감소

- 훈련을 받는 직원이 프로그램을 완수할 수 있도록 전략 수립

- 운영 과정 보고 기준과 방식 개선을 통해 일상적 업무 효율 증가

- 활동 기간의 연장 가능성 및 지원과 관련 해 관리자가 사전 공지할 수 있도록 관련 정책 수정

세부 목표 10. 글로벌 연계성(Global Connectivity)

- IT 시스템의 현대화와 통합, 현지에 있는 봉사단원과 직원들의 혁신에 영향력을 미쳐 모든 봉사단원과 직원의 커뮤니케이션 및 협력을 강화

$$
\begin{array}{l|r}
\text { 전략 \& 활동 } & \text { 성과목표 \& 측정지표 }
\end{array}
$$

- 데이터베이스의 유지 · 통합 - 접근법이 10.1: 통합기술 플랫폼 개발 - 2018년 이후 통합기술 플랫폼을 활용해 수월하도록 탐색 · 분석·보고지원 시스 템의 현대화

· 직원 간 정보 공유를 향상시키기 위해 피 스코 내부 전산망 현대화

· 데이터 품질과 연락망의 정보 접근성을

\section{성과목표 \& 측정지표}

로 증대

·책임자·주무 부서: Associate Director, Office of Management; Associate Director, Office of Global Operations/Director, Office of Overseas Programming and Training Support

- 협력 부서: Office of Human Resource Management; Office of Staff Learning and Development

· 근거 자료: 미국의 직접고용 국내외 직원 설문조사(EVS), 현지 고 용직원 설문조사(HCSS)

측정산식: 각 설문조사(EVS, HCSS)응답자 중 '만족' 또는 '매우 만족'이라고 응답한 직원 비율

9.2: 직원 근무기간 증가 - 2016년까지 평균 근속 연수를 4년으로 확대, 2018년까지 동 수준 유지

· 책임자-주무 부서: Director, Office of Human Resource Management

협력 부서: Office of Congressional Relations

근거 자료: 피스코 데이터 베이스(National Finance Center)

- 측정산식: 특정 회계연도에 피스코를 퇴사한 미국 직접고용 직원의 평균 근무 기간 기능 단일화

- 책임자 - 주무 부서: Chief Information Officer, Office of the Chief Information Officer

· 근거 자료: 피스코 행정 기록

· 측정산식: 기존 애플리케이션 중에서 퇴출된 애플리케이션 비율
제 I 장

\section{제II장}

포

커

제피장 
향상시키기 위해 현재 및 귀국 봉사단원, 102 현지 직원의 연락망 데이터베이스 통합

- 신규 정보기술 및 참고 자료 보관의 분명하 고 투명성 있는 위험평가 전략 구축

- 안내서, 교육 및 봉사단원이 자주 사용하 는 소셜미디어 등 의사소통 수단을 활용 함으로써 소통과 협력 활성화

- 진보된 기술 환경(예: 모바일 기기)과 호환 될 수 있도록 유연한 시스템, 플랫폼, 절 차 구축

· 피스코 혁신 과제나 크라우드소싱 등 단 원 주도의 해결 방안 지원

· 피스코 지식공유 플랫폼을 활용해 단원과 직원이 사업 및 행정을 관리하고 우수 사 례 등을 확인
10.2: 지식공유 촉진 - 피스코에서 제공한 디지털 자료를 활용해 업무를 수행한 봉사단원 비율을 2018년까지 85\%로 증대

※ 지식공유 플랫폼을 통한 디지털 접근성 향상은 봉사단원과 직원의 프로젝트 정보 저장·검색을 지원함. 그 예로 PCLive는 봉사단원과 직원을 위한 피스코의 주요 지식정보 공유 플랫폼임.

- 책임자-주무 부서: Associate Director, Office of Global Operations; Director, Office of Overseas Programming and Training Support

- 협력 부서: Office of the Chief Information Officer; Office of Innovation

· 근거 자료: 연례 봉사단원 설문조사

- 측정산식: 응답자 중에서 매월 1회 이상 디지털 자료를 활용한다고 응답한 봉사단원 비율

세부 목표 11. 결과 측정(Measurement for Results)

- 통합 모니터링, 보고(reporting), 평가를 실행해 봉사활동 성과 측정, 성과 개선, 영향(impact)의 증명에 대한 피스코의 역량 증진

\begin{tabular}{r|r}
\hline 전략 \& 활동 & 성과목표 \& 측정지표
\end{tabular}

- 매년 기관 평가 어젠다를 활용해 향후 우 11.1: 기초선조사 수행 - 2016년까지 기초선 데이터 수집 비율을 선순위 설정

- 본부 및 현지 사무소를 대상으로 평가 보고·모니터링 안내서 제공 및 전 기관 에서 평가 시스템 실행

· 봉사단원, 현지 직원, 파트너에게 M\&E . 보고에 대한 교육 제공

· 분석 담당 직원의 모집 요강을 수정하고, 분석 위주의 훈련을 제공함으로써 데이터 분석 담당 직원 및 기관의 역량 강화

- 기초선 데이터를 수집해 봉사활동의 효과 성 평가

- 신규 데이터 개발, 기존 데이터 개선 그리 고 보고 및 성과의 단순화를 통해 데이터 의 품질, 접근성 및 시기적절성 향상 $100 \%$ 달성, 2018년까지 동 수준 유지

※ 베이스라인 데이터는 프로젝트 활동을 시작하기 전에 수집되며, 프로젝트 종료 후에 수집된 데이터와 비교됨.

·책임자 - 주무 부서: Associate Director, Office of Global Operations/Regional Directors/Africa Region; Europe, Mediterranean, and Asia Region; Inter-America and the Pacific Region)

· 협력 부서: Office of Strategic Information, Research and Planning; Office of Overseas Programming and Training Support; Office of Global Health and HIV/AIDS

· 근거 자료: 피스코 행정 기록

· 측정산식: 전체 신규 파견국와 신규 프로젝트 수에서 베이라인 데이터가 수집된 비율. 프로젝트 시작 전에 연구 설계와 주요 데이 터 수집이 완료되었다면 베이스라인 데이터 수집 노력이 진행 중 인 것도 동 성과 목표를 달성한 것으로 간주

11.2: 증거기반 의사결정 증대 - 2016년까지 정책 수립·예산 편성에 대한 근거를 활용하는 본부현지 비율을 100\% 달성, 2018년까 지 동 수준 유지

※ 동 성과지표에서 '증거(evidence)'란 명제가 사실인지 여부를 나타 내는 정보이자, 공식·비공식적 연구와 평가 활동을 통해 프로그 램 · 행정 - 예산 데이터를 수집 · 분석 및 보고하는 과정에서 파생 된 결론을 나타내는 정보임.

- 책임자 - 주무 부서: Director, Office of Strategic Information, Research and Planning

- 협력 부사: Africa Region; Europe, Mediterranean and Asia Region; Inter-America and the Pacific Region

· 근거 자료: 피스코 행정 기록

· 측정산식: 피스코 해외 부서(posts)와 본부 부서 총 정책, 프로그램, 예산의 의사 결정에서 증거 활용을 입증한 해외 부서와 본부 부서 의 비율 
11.3: 증거에 기반한 혁신 촉진 - 2017년까지 M\&E을 도입한 본부·현지 의 시범 운영 비율을 $100 \%$ 로 증대, 2018년까지 동 수준 유지

- 책임자. 주무 부서: Director, Office of Strategic Information, Research, and Planning

- 협력 부서: Africa Region; Europe, Mediterranean, and Asia Region; Inter-America and the Pacific Region

· 근거 자료: 피스코 행정 기록

- 측정산식: 파일럿(pilot)을 운영한 전체 해외 부서와 본부 부서에서 파일럿에 구조화된 모니터링과 평가를 활용한 비율

출처: 내용을 저자가 재구성

섹

2011년 5월부터 피스코는 표준분야지표(Standard Indicators, SIS)를 6개 분야에 사용하고 있다. 총 지표의 수는 347 개이며, 이는 2016년 기준으로 (1) 교육 분야 38 개, (2) 농업 분야 38 개, (3) 커뮤니티 분야 41 개, (4) 환경 분야 23 개, (5) 보건 분야 187 개, (6) 청년 분야 20 개를 포함한다(<표 6> 참고).

\section{〈표 6〉 피스코 봉사활동의 6 개 분야 지표 예시}

\begin{tabular}{|c|c|}
\hline 지표 & 지표내용 \\
\hline 교육 & $\begin{array}{l}\text { · 교사(영어 교수법): 교수법을 향상시킨 교사의 수(새로운 기술을 사용하거나, 더욱 효과적인 방법으로 영어 } \\
\text { 커뮤니케이션 향상) } \\
\text { · 교사영어 교사 커뮤니티 · 전문성 개발): 봉사자와 일했던 영어 교수들 중 영어 교사 전문성 개발 트레이닝 } \\
\text { 에 참여한 사람의 수 } \\
\text { · 교사영어 교사의 영어 실력 향상): 봉사자들과 함께 일한 영어 교사들 중 영어 실력이 향상된 사람의 수 } \\
\text { · 학생(영어 문해율): 읽기나 쓰기 능력이 향상된 학생의 수 } \\
\text { · 커뮤니티(교사 및 직원): 봉사자들과 일한 학교 관계자들 중 학교 행정 시스템을 발전시키거나 영어교육을 } \\
\text { 강화시킨 사람의 수 } \\
\text { · 커뮤니티(영어교육 도움): 봉사자들과 일한 공동체 주민 중 학교를 돕는데 필요한 활동을 하거나, 영어교육 } \\
\text { 을 촉진시키는 환동을 한 사람의 수 } \\
\cdot \text { 교사(문해율 교수법): 봉사자들과 일한 교사들 중 문해율 교수법을 발전시킨 교사의 수 } \\
\text { · 교사기본 읽기 능력): 봉사자들과 일한 교사들 중 기본적인 읽기 능력을 향상시킨 교사의 수 }\end{array}$ \\
\hline $\begin{array}{l}\text { 커뮤 } \\
\text { 니티 }\end{array}$ & 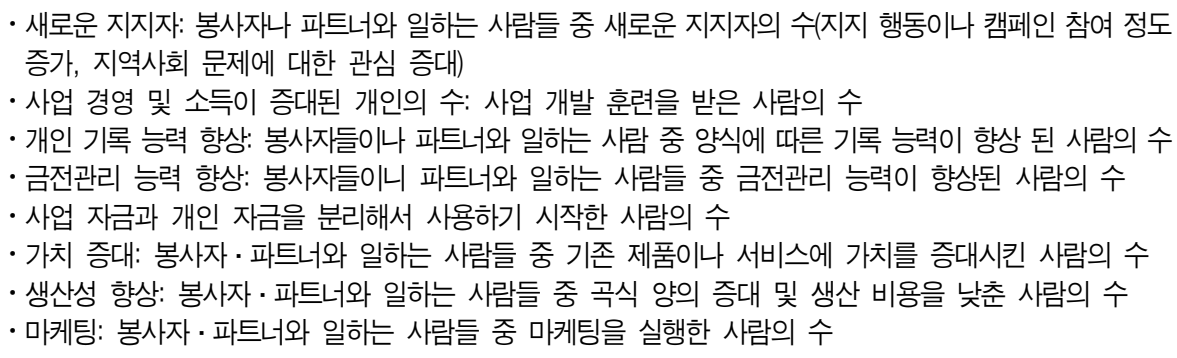 \\
\hline 환경 & $\begin{array}{l}\text { - 새롭게 향상된 환경: 봉사자 · 파트너의 도움으로 하나 또는 그 이상의 환경 이슈가 개선된 사례의 수 } \\
\text { - 환경교육: 봉사자·파트너와 함께 일한 사람들 중 그들의 수업에 환경 관련 내용을 향상시킨 교사의 수 } \\
\text { - 환경교육 자료 향상: 봉사자· 파트너의 도움으로 증가된 환경 관련 자료의 수 } \\
\text { · 환경 이슈에 대한 이해: 봉사자· 파트너와 일한 사람들 중 환경 이슈의 이유와 결과, 해결책에 관련되어 }\end{array}$ \\
\hline
\end{tabular}




\begin{tabular}{|c|c|}
\hline 지표 & 지표내용 \\
\hline & $\begin{array}{l}\text { 현저하게 지식이 증가한 사람의 수 } \\
\text { · 생태에 대한 이해: 봉사자· 파트너와 일한 학생들 중 생태계와 관련된 이슈에 대한 이해가 현저하게 증가한 } \\
\text { 학생의 수 } \\
\text { - 자연에 대한 감사: 봉사자· 파트너와 일한 학생들 중 자연과 지구 동물에 대한 아름다움, 특징 및 기여도에 } \\
\text { 대한 지식 및 고마움이 현저하게 증가한 학생의 수 } \\
\text { · 가정 내에서의 환경 시행: 봉사자 · 파트너와 일한 학생들 중 가정에서 환경 보호 및 관리와 관련된 기술을 } \\
\text { 적용한 학생의 수 } \\
\text { · 커뮤니티 자연 봉사활동: 봉사자들과 일한 학생들 중 지역 환경보호 이벤트에 참여한 학생의 수 }\end{array}$ \\
\hline 농업 & $\begin{array}{l}\cdot \text { 피스코의 도움으로 기술이나 경영 방법 등이 향상된 농부의 수 } \\
\cdot \text { 피스코의 도움을 받은 기관의 수 } \\
\cdot \text { 피스코가 지원하는 단기간 농업 생산성 프로ㅈㅔㅔ트나 식량 안보 훈련을 받은 사람의 수 } \\
\cdot \text { 봉사자· 파트너와 일한 사람들 중 곡물 생산량이 실제 늘어난 사람의 수 } \\
\cdot \text { 피스코의 도움을 받아 기후변화에 대응한 농사를 시행한 사람의 수 } \\
\cdot \text { 수질 자원(접근성): 봉사자 ·파트너의 도움으로 수원이나 관개시설이 새롭게 설치된 수 } \\
\cdot \text { 신기술 및 실행(분야별): 새롭게 향상된 기술과 관리 등을 통해 생산성이 향상된 지역의 넓이 } \\
\cdot \text { 토질을 발전시킨 사람의 수: 봉사자· ·파트너의 도움으로 토질을 향상시킨 사람의 수 }\end{array}$ \\
\hline 건강 & 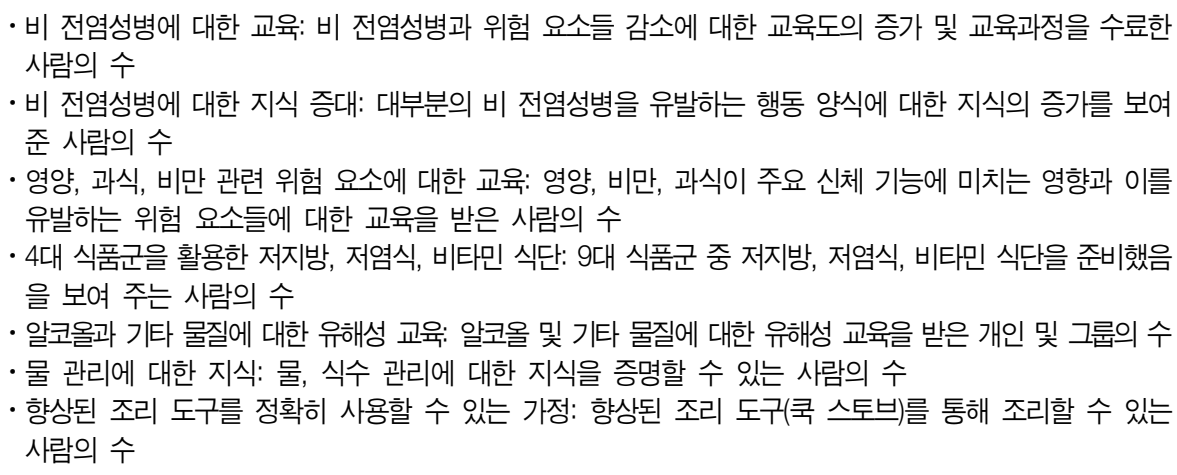 \\
\hline 청년 & 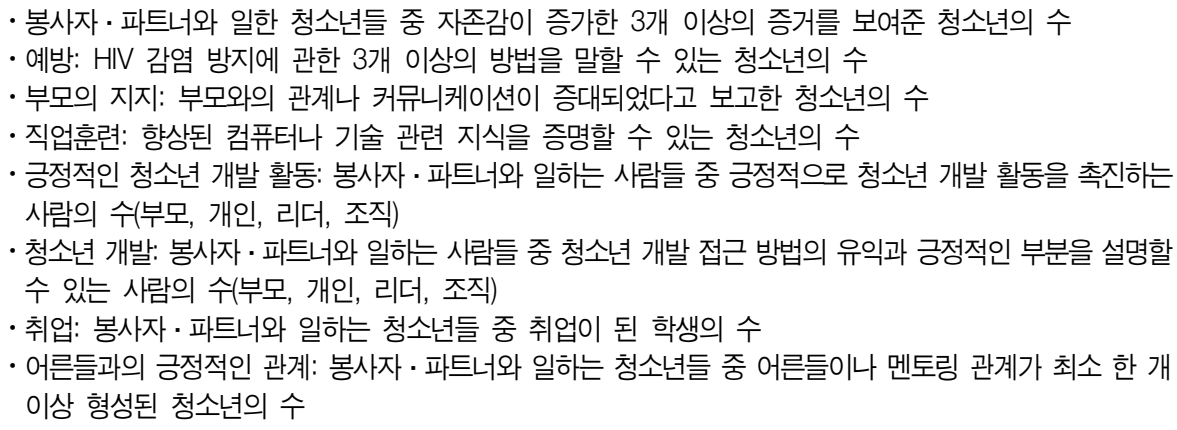 \\
\hline
\end{tabular}

출처: 자원봉사자 리포트시스템 자료센터

(https://pclive.peacecorps.gov/pclive/index.php/learn-explore/volunteer-tools/vrf) (접속일: 2017.3.21.)

위 <표 6>을 보면, 피스코는 지표에 따라 3가지 요소를 기본적으로 측정하고 있다. 프로젝트를 통한 가장 단기적인 변화는 지식의 변화(knowledge change), 중기적인 변화로는 기술 구현 차원 의 변화(skills demonstration) 그리고 중장기적인 변화는 행동의 변화(behavioral changes)로 구분할 수 있다. 이러한 변화를 측정할 때는 관찰 및 인터뷰를 방식을 활용하고 있다. 
또한 과학 교육 프로그램의 경우 측정 단위가 ‘학생들의 수’로 명기되어 있듯, 측정 단위가 명확하게 표기되어 있으므로 단원들이 데이터를 어떻게 수집해야 하는지 분명히 알 수 있다.

뿐만 아니라 프로젝트가 가져온 변화를 더 정확히 평가하기 위해 봉사자들은 프로젝트 초창 기에 지표를 설정해 측정하고, 프로젝트가 진행 중이거나 종료 후 동일한 지표를 통해 측정을 한다. 이를 통해 프로젝트의 진행에 따른 변화를 측정할 수 있다. 봉사자들은 최소 2 번 이상(프 로그램의 시작과 종료 후) 평가를 한다.

제I장

\section{제II장}

\section{3. 증거 기반의 성과 평가를 위한 데이터 수집 및 관리 전략2)}

피스코는 평가 및 연구에 대한 역량을 지속적으로 확대하고 있으며, 관련 근거 자료를 갖추는 것은 기관의 의사 결정과 봉사단원 및 기관의 효과성을 입증하는 데 도움을 주는 것으로 판단하 고 있다. 예를 들어, 피스코는 기존 데이터의 활용 역량을 강화하고, 기관 내 적절한 증거 기반 시스템을 구축하기 위해 봉사단원과 직원이 활용할 수 있는 모니터링, 보고, 평가의 훈련 방법과 수단을 개선하고 또 관련 평가 직원의 인원을 증가시키고 있다. 특히 피스코는 성과의 측정 및 증거 기반 접근법을 '2014-2018 전략 계획'의 목표 중 하나로 설정해 기관의 모니터링·보고. 평가 체계의 개선 및 확대를 위해 노력하고 있으며, 구체적인 활동은 <표 $7>$ 과 같다.

\section{〈표 7〉 피스코 증거 기반 성과목표 설정을 위한 증거 활용 사례}

\begin{tabular}{|c|c|}
\hline 증거 종류 & 증거활용 내용 \\
\hline $\begin{array}{l}\text { 기존 문헌 검토 } \\
\text { (Review of Existing } \\
\text { Studies) }\end{array}$ & $\begin{array}{l}\text { 피스코 종합 평가, 수원국 효과성 연구, 회계조사 등 } 40 \text { 여 개가 넘는 다양한 기관 내외부 } \\
\text { 보고서 및 연구자료를 검토함으로써 지속적으로 발생하는 문제를 파악하고 개선의 기회를 } \\
\text { 모색함. }\end{array}$ \\
\hline $\begin{array}{c}\text { 심층인터뷰 } \\
\text { (In-depth Interviews) }\end{array}$ & $\begin{array}{l}50 \text { 명이 넘는 직원과의 인터뷰를 통해 공동의 주제를 모색하고, 귀국 봉사단원 및 해외 직원과 } \\
\text { 의 심층 대화를 진행함. }\end{array}$ \\
\hline $\begin{array}{c}\text { 기관 작업반 } \\
\text { (Agency Work Groups) }\end{array}$ & $\begin{array}{l}\text { 본부, 해외 사무소, 지역 부서 등에서 활동하는 고위 간부 및 기술 전문가로 실무진을 구성해, } \\
\text { 피스코 직원의 특별 전문 기술과 개인적 노하우를 활용해 기존 문제를 파악하고 또 잠재적 } \\
\text { 목표의 우선순위를 정하며 문제 해결을 위한 전략 및 활동을 세부화 함. }\end{array}$ \\
\hline $\begin{array}{l}\text { 현지조사 } \\
\text { (Fieldwork at } \\
\text { Overseas Posts) }\end{array}$ & $\begin{array}{l}\text { 피스코 해외 파견 및 수원 기관 현지 관계자, 봉사단원 및 지역사회 수혜자들을 대상으로 } \\
\text { 인터뷰를 실시해 이들의 의견을 수집하고, 봉사단원 및 직원의 운영을 모니터링함. 예를 들어, } \\
\text { 여러 수원국가(모로코, 세네갈, 엘살바도르, 과테말라, 우크라이나, 파나마)에서 포커스 회의도 } \\
\text { 개최한 바 있음. }\end{array}$ \\
\hline $\begin{array}{l}\text { 기존 피스코 자료 분석 } \\
\text { (Analysis of Existing } \\
\text { Peace Corps Data } \\
\text { sources) }\end{array}$ & $\begin{array}{l}\text { 안전 - 안보, 건강, 지역개발 과정, 봉사단원의 파트너 등에 관해 봉사단원 선문조사 연간 데이 } \\
\text { 터 등 내부 자료를 활용함. 이를 통해 관련 활동 목표를 수립하고 전략 및 활동 사항을 분석함. } \\
\text { 특히 지역사회개발 및 미국인 이해도 증진에 관한 봉사단원의 기여를 분석하고자 현지 활동 } \\
\text { 분야별 기준지표를 활용하고, 관련 활동 목표를 구체화할 수 있음. }\end{array}$ \\
\hline
\end{tabular}

출처: Peace Corps (2016a) p.32 내용을 표로 재구성

2) 동 절은 Peace Corps (2016a) pp.32 3 내용을 요약 정리한 것이다. 
피스코는 성과 측정을 위해 기존에 수행하던 심층 인터뷰, 현지조사, 문헌연구 등의 방법뿐만 아니라 새로운 데이터 수집 방식을 고안 도입함으로써 성과 데이터의 신뢰성과 타당성을 보장 하기 위해 노력하고 있다. 특히 피스코의 전략정보·연구·기획부서(Office of Strategic Information, Research, and Planning)가 데이터의 정확성과 완성도를 관리·검토하고 있다. 피스코가 활용하는 증거 기반 성과 데이터는 아래와 같은 방식으로 축적된다.

\section{1) 단원 연례설문조사(Annual Volunteer Survey, AVS)}

단원 연례설문조사(Annual Volunteer Survey, 이하 AVS)는 현재 봉사활동을 수행하는 봉사단원을 대상으로 익명성을 보장하는 자발적 성격의 온라인 조사로, 봉사단원은 피스코 교육의 효과, 현지 직원의 지원, 봉사단원 개인의 건강 및 안전 그리고 전반적인 봉사활동 경험 등에 관해 응답한다. 2014년도 봉사단원 연례설문조사의 경우 약 3 개월간 이루어졌으며, 전체 피스코 단원의 $91 \%$ 가 설문에 참여했다. 높은 응답률을 보이는 설문조사일수록 전반적인 오류 를 최소화할 수 있지만, $\mathrm{AVS}$ 는 무작위 표본 방식이 아니기 때문에 일반적 설문조사처럼 무응답 편향(non-response bias)을 보이기도 한다(Peace Corps, 2016a: 35). 봉사단원이 직접 작성 한 $\mathrm{AVS}$ 의 모든 응답은 전자 기반 설문 데이터베이스에 보관된다. 이는 데이터 품질을 향상하기 위한 노력으로, 데이터 분석 단계 이전의 수집 단계에서 엄격한 정화 작업이 이루어진다. 이로써 데이터 분석을 통해 기관 내 관계자들은 주요 이슈에 대한 봉사단원의 관점을 파악할 수 있게 된다.

AVS는 데이터 품질을 향상하고 또 응답자의 비밀 보장을 강화하기 위해 2014년에 관련 문항을 대대적으로 수정했는데, 2013년 기준 105개에서 2014년 기준 55개로 문항 수를 대폭 줄이면서 데이터 품질 및 단원의 설문조사 경험(survey-taking experience)의 질을 향상코자 했다. 또한 전년도 데이터를 자세히 분석함으로써 문항 수정을 진행했으며, 응답자의 익명성 보장이 어렵거나 일반 봉사단원이 적절한 답변을 주기에 다소 힘든 문항의 경우에는 향후 설문 조사에서 모두 삭제되었다(Peace Corps, 2016a: 35). 예를 들어, 응답자의 정보 보안을 강화하 고자 모든 인구통계적 문항을 설문조사의 마지막 부분으로 이동했으며, 이로 인해 응답자는 실질적 문항에 모두 답한 후에 추가적으로 인구통계적 데이터에도 응답할지에 대해 더욱 명확하 게 판단할 수 있게 되었다.

이처럼 AVS의 방식이 항상됨에 따라(응답 규모의 변화, 응답자의 비밀 보장 향상, 설문조사 시간 단축) 2014년 결과가 전년도보다 긍정적으로 관찰되었는데, 이는 2014년에 향상된 여러 변화뿐만 아니라 활동 목표를 달성하기 위한 기관이 전사적으로 추진한 타 전략으로 인한 긍정 
적 결과라고 볼 수 있다(Peace Corps, 2016a: 35).

\section{2) 피스코 데이터베이스}

피스코는 봉사단원 및 봉사 활동에 대한 정보를 수집하기 위한 여러 데이터베이스 시스템을

보유하고 있다. 데이터의 정확성 보장 및 적절한 입력 방법을 구축하기 위해 적합한 훈련을 받은 직원만 시스템에 접근할 수 있도록 제한하고 있으며, 데이터베이스 관리 담당자는 기관 내 정기적인 조율 절차를 통해 데이터베이스를 확인한 후 데이터 입력의 분리 및 수정 그리고 오류 수정 등의 업무를 추진한다. 피스코 데이터베이스는 내부 자동화 시스템에서 적절히 관리 되고 있으며, 규칙성과 정확성을 최우선으로 한다(Peace Corps, 2016a: 36).

\section{3) 피스코 일반 행정 기록(Peace Corps administrative records)}

피스코는 본부와 해외 사무소에서 일반 행정적 데이터를 매년 수집한다. 이렇게 수집된 데이 터는 중앙 관리 데이터베이스가 아닌, 외부 전자 시스템에 저장된다. 따라서 모든 본부 및 현지 사무소의 관계자들은 설문조사에 의무적으로 임해야 하며, 데이터 분석 전 수집 단계에서부터 데이터 검열 절차가 이루어진다. 이때 데이터 입력 오류 및 예외적인 변수(anomalies)를 최소 화하기 위해 분명한 논리 모델과 규칙을 기반으로 설문조사를 설계하며, 피스코 전략정보·연구. 기획부서(Office of Strategic Information, Research, and Planning)에서 데이터를 독립적 으로 관리한다(Peace Corps, 2016a: 36).

\section{4) 직원 관점 설문조사(Employee Viewpoint Survey)}

직원 관점 설문조사는 효율적인 현장 관리 방안에 대한 직원의 의견을 수렴하기 위해 모든 피스코 직원을 대상으로 매년 실시된다. 설문조사 결과를 활용해 피스코의 업무 여건을 다른 정부기관과 비교하고, 더 나아가 업무 관리를 향상할 방법을 강구한다. 설문조사 시 응답자 샘플은 피스코의 모든 직원을 대상으로 하며, 2014년에는 직원의 93\%가 설문조사를 완료했다. 미 연방정부의 인사관리 부서에서 매년 시행하는 연방공무원 관점의 설문조사를 토대로 문항을 구성했으며, 조사는 컴퓨터를 통해 이루어진다. 설문조사는 어느 한 시점에서 직원의 관점만을 대표하는 단면적인 자료만을 제공하기 때문에 기타 외부 요소에 의해서도 영향을 받는다. 피스 코는 이러한 한계를 보완하고자 다른 정부기관의 데이터와 비교함으로써 다년간의 변화를 토대 로 적절한 결론을 이끌어 내고 있다(Peace Corps, 2016a: 37). 


\section{5) 봉사단원 보고 도구(Volunteer Reporting Tool, VRT)}

봉사단원 보고 도구(Volunteer Reporting Tool, 이하 VRT)는 봉사단원의 활동 내용과 활동 진행 사항 혹은 기관의 전략적 파트너십에 대한 봉사단원의 기여를 기록하기 위해 마련된 도구다(Peace Corps, 2016a: 37). 2008년 이후 봉사단원의 활동 보고는 전자 방식의 VRT를 통해 이루어졌으며, 2014년에 VRT 개선 작업이 완료되었다. 개선된 VRT는 사용자 위주의 인터페이스 제공, 봉사단원의 종합 데이터 구축 그리고 관련 데이터의 품질을 개선시켰다. 특히, 2014년 이후 새로운 버전의 VRT를 활용함으로써 봉사단원의 활동 및 성과에 대한 일관적이며 더 많은 데이터를 수집하게 되었고, 봉사단원의 효과성을 증명하기 위한 모니터링과 분석 그리 고 보고가 훨씬 수월해졌다.

예를 들어, VRT를 활용하기 시작하면서 데이터 입력의 오류를 줄이고, 보고 체계와 대상자의 경험을 향상시킬 수 있었다. 봉사단원은 VRT를 통해 해외 사무소에 분기별 혹은 반기별 보고서 를 제출하는데, 직원들은 모든 보고서를 검토하고 데이터를 확인하며 또 오류(anomalies)를 수정해 최종 분석을 마무리한다. 한편, 피스코는 VRT 관련 심층 훈련을 제공해 봉사단원과 직원에게 데이터의 올바른 수집, 분석, 보고에 대해 교육한다. 또한 피스코는 VRT를 활용하기 에 앞서 봉사단원의 데이터 수집 방법을 표준화하고자 활동 목표와 관련된 지표에 대한 데이터 수집 방안을 마련한 바 있다(Peace Corps, 2016a: 37).

\section{6) 글로벌 카운터파트 설문조사(Global Counterpart Survey)}

2014년도에 해외 사무소 직원들이 처음 시행한 글로벌 카운터파트(counterpart) 설문조사 는 현지 주요 파트너와의 짧은 인터뷰로 이루어졌다. 봉사단원이 지역사회에 미친 영향력에 관한 정보를 제공하기 위해 20 개의 설문 문항이 설계되었고, 봉사단원과 가장 가깝게 일한 사람들이 이에 응답했다. 설문조사는 예정 지역에 정기적으로 방문하는 해외 사무소 직원들에 의해 일 년 동안 꾸준히 진행되었다.

글로벌 카운터파트 설문조사는 사업 현장과 상대 파트너와의 의사소통을 경험한 직원을 대상 으로 인터뷰를 시행하기 때문에 데이터 수집의 오류 및 모호성 등의 방지를 위한 데이터의 품질관리 필요성이 주요한 과제로 남아있다. 예를 들어, 직원들이 광범위한 설문 인터뷰나 데이 터 수집 경험이 적을 수 있으며, 또한 번역 및 인터뷰 형식의 다양성과 코딩의 정확성 결여는 설문 결과에 예상치 못한 영향을 끼칠 수 있다. 따라서 피스코 기관 차원에서 훈련을 제공함으로 써 이러한 과제를 다루고 있다. 
또 다른 과제는 설문조사 대상자를 명확히 설정하는 작업이다. 기관마다 '파트너'에 대한 다양 한 활용과 해석이 존재하는데, 이는 설문조사 대상자에 영향을 줄 수 있는 중요한 요인이다. 피스코의 경우, '파트너'를 봉사단원의 주요 활동을 위해 함께 협력하는 상대방으로 설정하고 있다. 예를 들어, 활동 목표 3.2 (지역 역량 강화)와 4.1 (미국인 관련 이해 증대)의 목표를 달성하기 위해 각 봉사단원은 한 명의 '파트너'와 공식적으로 협력하고 있다(Peace Corps, 2016a: 37).

\section{7) 수원국 직원 설문조사(Host Country Staff Survey)}

피스코는 2014년에 체계적인 수원국 직원 설문조사를 처음으로 시행했다. 동 설문조사는 자발적 성격의 간단한 설문조사 방식으로, 2014년 7월 31일부터 9월 2일 사이에 진행된 온라인 설문조사에서는 전체 수원국 직원의 $37 \%$ 가 응답했다. 설문조사에는 기관의 다양성 강화 및 직원 교육의 필요성과 관련된 8가지 문항이 포함되었다. 피스코는 향후 현지 운영과 지원에 관한 수원국의 입장을 지속적으로 수집할 수 있도록 추가 문항을 구성할 계획이다.

한편, 수원국 직원 설문조사 데이터의 질적 향상을 위해 표본추출 틀을 개선해야 한다는 지적이 지속되고 있다. 예를 들어, 2014년 수원국 직원 설문조사의 경우 당시의 표본추출 프레임 은 이메일로 연락이 되는 수원국 직원들로만(전체 2,900명 중 약 1,850 명 포함) 구성되었고, 이중에서도 58\% 정도만 설문조사에 응답했다는 한계가 있었다. 이는 컴퓨터와 같은 전자기기 의 부족, 온라인 설문조사 방법에 대한 이해도 차이, 영어 실력의 격차 등이 무응답을 이끄는 요인이 되었기 때문이다. 따라서 피스코는 설문 문항을 다양한 언어로 작성해 더 많은 수원국 직원의 참여를 장려하고자 한다(Peace Corps, 2016a: p.38).

\section{8) 이해관계자의 참여(Stakeholder Engagement)}

피스코는 데이터 수집에 다양한 이해관계자를 포함하기 위해 참여 주도적이며 포괄적인 전략 수립 절차를 활용한다. 본부 및 현지 주요 직원, 수원국 관계자, 봉사단원, 지역사회 수혜자 등 다양한 이해관계자들과 회의, 인터뷰, 포커스 그룹 토론을 거쳐 기관의 목표 및 전략을 수립 한다. 또 자문 과정에도 귀국 봉사단 모임과 주요 전략 파트너들이 참여하고 있다.

예를 들어, 2013년 11월 8일부터 12월 2일까지 약 한 달간 피스코 공식 웹사이트에 '2014 2018 전략 계획(Peace Corps Strategic Plan 2014 2018)'의 예비 계획안을 게재했으며, 여기에 피스코는 귀국 봉사단원, 파트너, 일반 시민 등 다양한 이해관계자의 피드백을 수집해 향후 전략 수립에 반영한 바 있다. 
이러한 노력뿐만 아니라 피스코는 2012년 9월 '2009 2014년 전략 계획'에 근거해 의회 위원회(Congressional Committees) 자문을 시행해 추후 전략계획 수립에 반영한 바 있으며, 의회와 함께 정책 및 예산의 중요성과 관련한 토의를 진행하고, 이를 통해 의회의 입장을 전략계 획에 반영하고자 노력하고 있다(Peace Corps, 2016a: 39).

\section{9) 기관 차원의 연간평가 의제(Annual agency-wide evaluation agenda)}

피스코의 연간평가 의제는 연례 전략의 검토 결과, 분기별 활동 전략 주요 주제, 기관의 우선순위 및 관심사 등을 고려해 매년 새롭게 구성된다. 몇 가지 주요 평가 주제로는 (1) 봉사단 원 모집의 신규 절차, (2) 미흡한 성과를 보인 활동 목표 확인, (3) VRT와 같은 봉사 활동 모니터링 수단 검토 등이 있다. 이러한 기관 차원의 연간평가 의제는 효과적인 봉사단 운영을 위한 근거 자료로 사용될 수 있다는 장점이 있다(Peace Corps, 2016a: 34).

\section{0) 영향력 평가(Impact evaluations)}

2014년에 피스코는 코소보에서 기초선 데이터 수집 프로젝트를 시행했다. 코소보는 2014년 이전까지 피스코 단원이 활동한 적이 없는 국가였다는 점에서 기초선 데이터 수집에 적합한 국가라고 할 수 있다. 일반적으로 해외 봉사 파견 기관은 수원국 지역사회와 봉사단원이 일정 기간 교류한 이후의 종료 데이터(endline data)만을 수집하는데, 종료 데이터를 기초선 데이터 와 함께 분석하면 지역사회 개발 성과에 대한 봉사단원 활동의 영향과 현지 주민들의 미국인에 대한 인식을 더 정확히 평가할 수 있다(Peace Corps, 2016a: 34). 


\section{III. 영국 해외시민봉사단(ICS)}

\section{1. 개요}

영국 해외시민봉사단(International Citizen Service, 이하 ICS)은 영국국제개발부 (Department for International Development, 이하 DFID)가 2011년 출범시킨 해외 봉사단 이다. 영국 해외 봉사단(Voluntary Service Overseas, 이하 VSO) 주도로 시행되고 있으며, VSO 외에도 Balloon Ventures, Challenges Worldwide, International Service, Raleigh International, Restless Development, Tearfund, Y Care International이 운영을 담당하 고 있다.3) VSO를 거점으로 하는 'ICS 본부·허브(Hub)'가 ICS 사업을 관리하며 프로그램 품질 을 담당하고 있으며, ICS의 목적은 극빈한 지역사회에서의 긍정적 개발 성과 달성 및 영국 청년들 의 국제 개발에 대한 인식 제고와 함께 참여적 시민 의식 양성을 포함한다(DFID, 2013: 1).

〈표 8〉ICS가 목표하는 성과

\begin{tabular}{|c|c|}
\hline 성과 영역 & 내용 \\
\hline $\begin{array}{c}\text { 봉사단원의 성장 } \\
\text { (Volunteer Development) }\end{array}$ & 영국 및 현지 봉사단원이 개인적 - 전문적 수준에서 성장 \\
\hline $\begin{array}{c}\text { 현지 개발 } \\
\text { (In-country Development) }\end{array}$ & 프로젝트 파트너와 수원국 지역사회의 개발 도모 \\
\hline $\begin{array}{c}\text { 적극적 시민성 } \\
\text { (Active Citizenship) }\end{array}$ & $\begin{array}{l}\text { 새로운 봉사단원 및 옹호에 용기를 심어 줌으로써 ICS 귀국 단원들 } \\
\text { 로 인해 영국 및 현지 지역사회에서 더 광범위한 봉사 활동 및 다른 } \\
\text { 형태의 사회적 활동을 전개 }\end{array}$ \\
\hline
\end{tabular}

출처: DFID (2013) p.20 내용을 저자가 재구성

이처럼 ICS의 세 가지 성과 영역은 서로 연계되어 있으며, 그 중요성과 초점이 동일하게 분배되어 있다. 따라서 ICS는 이 세 가지 성과를 달성함으로써 영국뿐만 아니라 전 세계의 경제적·사회적·환경 개발에 장기적이며 긍정적인 영향을 가져다줄 것이라고 믿는다(DFID, 2013: 20).

$\mathrm{ICS}$ 의 특징은 성과평가 대상이 청년 중심이며, 봉사 활동의 궁극적 목표가 봉사단원의 적극 적인 시민성(active citizenship) 배양이라고 할 수 있다. 이는 귀국 단원의 해외 봉사활동 경험을 사회에 환원하는 것에 가치를 두고 있다는 것으로 볼 수 있다. 평가 방법으로는 귀국

3) ICS 홈페이지를 참조하기 바란다. https://www.volunteerics.org/our-partners (접속일: 2017.11.15.) 
단원을 포함해 다양한 이해관계자들을 대상으로 만족도조사, 인터뷰(전화, 이메일, 면담), 관찰, 예산 보고 문서 및 시스템 분석, 7 개국(볼리비아, 엘살바도르, 인도, 네팔, 케냐, 탄자니아, 우간 다) 현장연구 등이 이루어진 바 있다(이태주 외, 2016: p.38).

$\mathrm{ICS}$ 가 가장 최근에 진행한 1차 평가(phase 1)는 2012년 10월에 위탁기관에 의해 수행되었 고, 2차 평가(phase 2)는 2014 2015년에 진행되었으며, 2차 평가에서는 행동 변화 및 장기적 결과를 중점적으로 다룬 바 있다(DFID, 2013: 4).

\section{2. 논리모형 및 지표와 문항}

ICS 프로그램의 논리모형은 변화이론에 초점을 두고 있다(DFID, 2013: 7). 또한 ICS의 성과 논리모형은 프로그램에 대한 기록과 문서, 기존 문헌 검토, $\mathrm{DFID}$ 및 관계자들과의 논의를 통해 개발되었다. (아래<표 9> 참고)

\section{〈표 9〉ICS 봉사사업 프로그램 성과 논리모형}

\section{투입 및 활동} 영국 봉사단원의 선발, 훈
련, 배치 지원

파견 지역(수원국)

봉사단원의 선발, 훈련, 배 치 지원

\begin{tabular}{|l|}
\hline 청년봉사단원의 봉사 활 \\
동을 수혜받는 수원국 지 \\
역사회 - 사업 확인
\end{tabular}

출처: DFID (2013) p.8 내용을 저자가 재구성

영국 봉사단원 및 수원국 봉사 단원의 봉사 활 동 착수 및 활동 종료

\section{단기적 결과 \\ 장기적 결과}

영향

\begin{tabular}{|c|c|}
\hline \multicolumn{2}{|c|}{ 수원국 현지 사업 개발 } \\
\hline $\begin{array}{l}\text { 수원 기관과 지역사 } \\
\text { 회에서 자원, 활동, }\end{array}$ & $\begin{array}{l}\text { - 수원 기관 및 지역사 } \\
\text { 회의 행동적· 물질 } \\
\text { 적 변화 }\end{array}$ \\
\hline $\begin{array}{l}\text { 청년층에 대한 태도 } \\
\text { 와 인식 변화 } \\
\text { 인프라 개발 }\end{array}$ & $\begin{array}{l}\text { 수원국 지역사회 스 } \\
\text { 스로 개발을 지원할 } \\
\text { 수 있는 역량 강화 }\end{array}$ \\
\hline
\end{tabular}

향후 봉사 활동 및 사회적 활동 국제 및 지역사회 개 발 옹호 개인적 책임감 및 변 화(transformation) 취업 - 교육 - 훈련 에 대한 기회 향상 동기 부여 네트워크 증진 변화에 대한 영감과

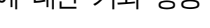

영국과 수원 국에 장기적 경제 - 사회 · 환경 개발

현지 개발 목표에 기여 
위와 같은 변화이론을 기반으로 한 ICS의 성과 평가 접근법은 투입물·활동, 결과물, 산출물, 영향력, 각 단계의 ICS 기여도 그리고 기타 외부요인의 잠재적 영향 등의 상관관계를 보여 준다.

아래의 <표 $10>$ 은 위 <표 9>의 ICS 성과 논리모형에 기반을 둔 몇 가지 지표 풀을 보여 준다.

〈표 10〉ICS 봉사사업 성과평가 데이터 및 지표 pool

\begin{tabular}{|c|c|}
\hline 분류 & 데이터 및 지표 \\
\hline 투입물 및 활동 & $\begin{array}{l}\text { · 홍보 캠페인의 종류, 범위, 횟수, 성공적 지원 유도 횟수(인원 등) } \\
\text { · ICS 웹사이트(주요 페이지) 순 방문자의 인원 } \\
\text { · 지원자 인구학적 프로필 및 인원(봉사단원과 팀 리더 포함) } \\
\text { · 평가 시행 횟수(그리고 참여율) } \\
\text { · 평가에 참여한 사람의 인구학적 프로필 및 인원 } \\
\text { · 선발된 지원자의 인구학적 프로필과 인원(연기 또는 거절한 \%) } \\
\text { · 훈련 세션의 횟수(그리고 참여율) } \\
\text { · 수원 기관이 활동에 참여한 횟수 } \\
\cdot \text { 귀국 봉사단원을 위한 행사 개최 횟수(그리고 참여율) } \\
\text { · 동문 행사· 활동의(종류별) 개최 횟수와 참여 인원 }\end{array}$ \\
\hline 산출물 / 결과물 & $\begin{array}{l}\cdot \text { 활동을 시작한 봉사단원의 인원 } \\
\text { · 활동을 완료한 봉사단원의 인원 } \\
\text { · 프로그램에 대한 만족도 }\end{array}$ \\
\hline $\begin{array}{l}\text { 단기 결과물 } \\
\text { (봉사단원 측면) }\end{array}$ & $\begin{array}{l}\cdot \text { 빈곤, 평등, 개발에 대한 인식 } \\
\cdot \text { 자신감과 기술 개발 } \\
\cdot \text { 다문화에 대한 이해 및 네트워크 } \\
\cdot \text { 변화를 이끄는 영감 및 동기 부여 }\end{array}$ \\
\hline $\begin{array}{l}\text { 단기 결과물 } \\
\text { (수원 기관 측면) }\end{array}$ & $\begin{array}{l}\text { - 파트너 기관 및 지역사회의 자원 조달, 훈련, 인식의 변화 } \\
\text { · 청년에 대한 태도와 관점 } \\
\text {. 인프라 개발 }\end{array}$ \\
\hline $\begin{array}{l}\text { 장기 결과물 } \\
\text { (봉사단원 측면) }\end{array}$ & $\begin{array}{l}\cdot \text { 추가적인 봉사 환동 및 사회적 활동 } \\
\cdot \text { 국제 및 지역사회 개발에 대한 옹호 활동 } \\
\cdot \text { 개인적 발전 및 변화 } \\
\cdot \text { 고용·교육·훈련 기회 개선 }\end{array}$ \\
\hline $\begin{array}{l}\text { 장기 결과물 } \\
\text { (수원기관 측면) }\end{array}$ & $\begin{array}{l}\text { · 관련된 파트너 기관 및 지역사회의 주요 행동적·물리적 변화 } \\
\text { · 수원국 지역사회가 개발을 스스로 지원하는 역량 }\end{array}$ \\
\hline
\end{tabular}

출처: DFID (2013) pp.14 15 내용을 저자가 재구성

위 <표 10> 내용을 기반으로, ICS는 5가지 방면에서 성과평가를 시행하고 있다. 성과평가 분야는 (1) 봉사사업 운영과 전달(process and delivery), (2) 봉사단원 측면 성과(volunteer outcomes), (3) 개발도상국 측면 성과(in-country outcomes), (4) 적극적 시민성 관련 결과 (active citizenship outcomes), (5) 금전적 가치(value for money)를 포함한다(DFID, 2013: $1 \sim 2$ ). 아래<표 $11>$ 은 ICS의 주요 성과평가 기준과 주요 질문을 더욱 세부적으로 보여 준다. 
〈표 11〉ICS 봉사사업 성과평가를 위한 분야별 세부 질문

\begin{tabular}{|c|c|}
\hline 분야/기준 & 중점 질문 \\
\hline $\begin{array}{l}\text { 근거 및 } \\
\text { 관련성 }\end{array}$ & $\begin{array}{l}\text { · ICS의 봉사 활동은 특정 필요(수요) 및 기회를 얼마나 고려했는가? } \\
\text { · 관련 시장 활동 등을 고려할 때, 어느 정도의 봉사 활동 및 투자가 적절한가? } \\
\text { · 봉사 사업이 정치적 · 전략적 맥락을 얼마나 반영했는가? } \\
\text { · 봉사 사업이 정치적 · 전략적 맥락의 변화에 연관성이 얼마나 있는가? }\end{array}$ \\
\hline 가격 & $\begin{array}{l}\text { · 봉사 사업을 수행하기 위한 비용은 어떤 것이 있는가?(주요 비용은 무엇인가?) } \\
\text {. 봉사 사업에 필요한 투입물이 적당한 가격으로 책정되었는가? } \\
\text { · 가격 조정 및 조달 자금의 적정 수준을 유지하기 위해 어떤 조치를 취했는가? }\end{array}$ \\
\hline 비용 효율성 & $\begin{array}{l}\text { · 단원 } 1 \text { 인당 비용, 전체 활동비용, 활동 각 단계에서 발생하는 비용은 얼마인가? } \\
\text {. 산출물의 합리적 비용을 달성하기 위해 어떠한 과정이 이루어졌는가? } \\
\text {. 수익 창출을 위한 기금 마련이 성공적이었는가? }\end{array}$ \\
\hline 효과성 & 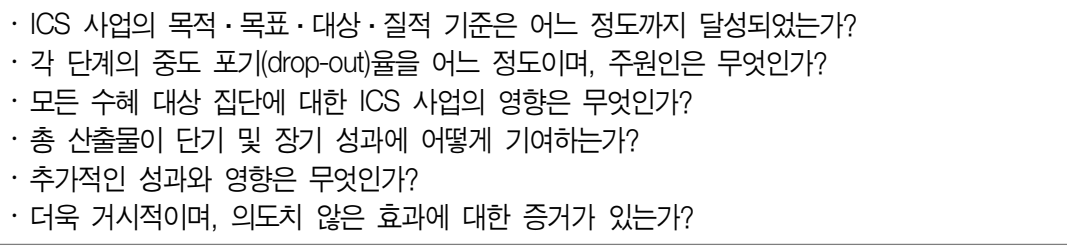 \\
\hline $\begin{array}{c}\text { 부가가치 } \\
\text { (Added value) }\end{array}$ & $\begin{array}{l}\text { · 봉사 사업이 다른 어떠한 기금이나 현물 지원에 영향을 미치는가? } \\
\text { · 사업을 통해 시너지 효과 및 타 사업과의 연계가 성공적으로 확대되었는가? } \\
\text { · ICS와 타 활동 사이의 연계는 양쪽 활동에 모두 부가가치를 더하는가? } \\
\text { · 봉사 사업이 이해관계자의 우선순위 및 지출 계획에 영향을 미치는가? } \\
\text { · 봉사 사업은 파트너의 서비스 전달 접근법에 영향을 주는가? } \\
\text { · 봉사 사업이 새롭고 혁신적인 접근법을 개발하는가? } \\
\text { · 봉사 사업이 반복 가능한 우수 사례를 만들었는가? 이는 얼마나 확산 · 전파되었는가? }\end{array}$ \\
\hline 지속 가능성 & $\begin{array}{l}\text { · 성과에 영구적인 변화를 이끄는 활동에 대해 어떠한 지표가 있는가? } \\
\text { · 참여자들의 더 많은 변화와 혜택을 위한 지원은 얼마나 이루어졌는가? }\end{array}$ \\
\hline $\begin{array}{l}\text { 프로세스 및 } \\
\text { 서비스 전달 }\end{array}$ & $\begin{array}{l}\cdot \text { ICS 사업이 어떻게 운영되는가? } \\
\cdot \text { 모집, 마케팅, 의사소통, 참여와 관련한 접근법에서 나타나는 강점과 단점은 무엇인가? } \\
\cdot \text { 평가, 훈련, 파견 전 지원의 과정이 얼마나 효율적인가? } \\
\cdot \text { 포괄적 접근법을 얼마나 성공적으로 이행했는가? } \\
\cdot \text { 파견 단계의 강점 및 약점은 무엇인가? } \\
\cdot \text { 파견 후 단계의 강점 및 약점은 무엇인가? } \\
\cdot \text { 사업의 다양한 단계를 효과적으로 연계하는 방법은 무엇인가? } \\
\cdot \text { 관리 및 모니터링 접근법을 통해 얻을 수 있는 교훈은 무엇인가? } \\
\cdot \text { ICS 본부가 데이터를 얼마나 효과적으로 파악하고 활용했는가? } \\
\cdot \text { 프로그램의 설계와 전달에 대한 정보를 ㅇㅓㅓㄱㅣ 위해 청년층을 얼마나 효과적으로 참여시켰는가? } \\
\cdot \text { 협력체 · 연합 구축 및 파트너 간의 협력 관계 구축은 얼마나 효과적인가? } \\
\cdot \text { 사업을 통한 교훈과 우수 사례를 얼마나 효과적으로 적용했는가? } \\
\cdot \text { ICS의 향후 파견 및 해외 청년봉사단 파견 계획을 위한 교훈은 무엇인가? } \\
\cdot \text { 어느 정도의 제언을 도출할 수 있는가? }\end{array}$ \\
\hline
\end{tabular}

출처: DFID (2013) pp.14 15 내용을 저자가 재구성

앞서 거론한 피스코와 마찬가지로, $\mathrm{DFID}$ 는 $\mathrm{ICS}$ 의 논리모형과 평가 기준을 토대로 다양한 방법론을 적용해 성과측정을 위한 증거를 수집하고 있다. 아래<표 $12>$ 는 성과 데이터 수집의 구체적인 전략과 방법을 요약해 보여 준다. 
〈표 12〉ICS 봉사사업 성과 데이터 수집 방법과 전략

\begin{tabular}{|c|c|}
\hline \multicolumn{2}{|r|}{ 1차 평가(phase 1) } \\
\hline 방법 & 연구 수행 실적 \\
\hline $\begin{array}{c}\text { 데이터 } \\
\text { 모니터링의 검토 }\end{array}$ & $\begin{array}{l}\text { DFID에 제출된 분기별 모니터링 보고서를 검토하고, ICS Hub가 제공한 추가적인 정보도 함 } \\
\text { 께 검토(서비스 전달, 마케팅, 재무 데이터 등 포함) }\end{array}$ \\
\hline 관찰 & $\begin{array}{l}\text { 파견 전 훈련, 귀국 봉사단원 행사 개최 등의 과정을 관찰하고 직원, 지원자, 봉사단원으로부 } \\
\text { 터 비공식적 피드백을 수집 }\end{array}$ \\
\hline $\begin{array}{l}\text { 이해관계자 } \\
\quad \text { 자문 }\end{array}$ & $\begin{array}{l}\text { ICS Hub 및 기관 직원, 다른 이해관계자와의 반 구조화 인터뷰를 통해 활동에 대한 적절한 } \\
\text { 근거· 전략, 성취도, 과정 그리고 부가가치 분석 }\end{array}$ \\
\hline 봉사단원조사 & 설문조사 응답을 분석해 봉사단원과의 질적 토론을 사례연구 방문 기간 동안 시행 \\
\hline $\begin{array}{l}\text { 봉사 비참여자 } \\
\text { 설문조사 }\end{array}$ & $\begin{array}{l}\text { ICS 지원 동기 및 ICS 비참여자의 비참여 이유 조사, 동 참여자 및 비참여자들의 특성과 동 } \\
\text { 기 비교 }\end{array}$ \\
\hline $\begin{array}{l}\text { 수원 기관 } \\
\text { 설문조사 }\end{array}$ & $\begin{array}{l}\text { 파트너 기관 설문조시를 통해 활동 과정을 분석하고, 파트너 및 지역사회와 관련성이 높은 개 } \\
\text { 발 결과물에 대한 주요 근거를 수집 }\end{array}$ \\
\hline 사례 연구 & $\begin{array}{l}\text { 봉사단원, 활동 과정, 개발 성과에 대한 상세한 근거를 수집하기 위해 봉사단원(영국과 현지 } \\
\text { 모두), 파트너 기관 직원, 사업 수혜자, 기타 이해관계자를 대상으로 한 관찰, 인터뷰, 방문 등 } \\
\text { 사례 연구 완료 }\end{array}$ \\
\hline \multicolumn{2}{|r|}{ 2차 평가(phase 2) } \\
\hline 방법 & 연구 계획 \\
\hline 문헌 연구 & DFID에 제출한 분기별 모니터링 보고서, 기관 보고서, 전략-정책 흐름 및 관련 문헌을 검토 \\
\hline $\begin{array}{l}\text { 이해관계자 } \\
\quad \text { 자문 }\end{array}$ & $\begin{array}{l}\text { 활동의 적절한 근거-전략, 성취도, 과정, 부가가치 달성을 분석하기 위해 주요 직원 및 기타 } \\
\text { 이해관계지를 대상으로 반구조화 인터뷰 진행 }\end{array}$ \\
\hline 관찰 & $\begin{array}{l}\text { 파견 기관에서 개최된 파견 전 훈련 및 귀국봉사단원 행사 등의 주요 일정에 참여하여 과정을 } \\
\text { 관찰하고, 직원·지원자·봉사단원으로부터 비공식적 피드백을 수집 }\end{array}$ \\
\hline $\begin{array}{l}\text { 봉사 비참여자 } \\
\text { 설문조사 }\end{array}$ & $\begin{array}{l}\text { ICS 지원 동기 및 ICS 비참여자의 비참여 이유 조사, 동 참여자 및 비참여자들의 특성과 동 } \\
\text { 기 비교 }\end{array}$ \\
\hline 후속 질적조사 & 약 25명의 봉사단원 샘플로 세 번의 전화 인터뷰를 진행해 장기적인 시민 행동을 조사 \\
\hline $\begin{array}{l}\text { 수원기관 } \\
\text { 설문조사 }\end{array}$ & 수원 기관 및 지역사회의 성과를 분석하기 위해 파트너 기관에 대한 추가적인 설문조사 실시 \\
\hline 사례 연구 & $\begin{array}{l}\text { 수원 기관의 개발 성과에 대한 상세한 근거를 수집하기 위해 봏사단원(영국과 현지 모두), 파 } \\
\text { 트너 기관 직원, 사업 수혜자, 기타 이해놘계자를 대상으로 관찰, 인터뷰, 방문조사 등을 포함 } \\
\text { 해 8개의 사례조사 실시 }\end{array}$ \\
\hline $\begin{array}{l}\text { 사회적 } \\
\text { 투자 수익률 }\end{array}$ & 성과에 관한 증거 등을 반영해 사회적 투자 수익률(Social Return on Investment, SROI) 분석 \\
\hline
\end{tabular}

출처: DFID (2013) p.16, 18 내용을 저자가 재구성

다음은 ICS의 성과평가를 위한 지표 중에서도 한국의 WFK 사업에서 중요하게 여기는 봉사단원 측면, 개발도상국 측면 성과측정을 위한 구체적 측정 문항을 정리해 보았다.

\section{1) 봉사단원 측면성과}

봉사단원 측면성과 측정을 위해 첫째, 단원들은 아래 <표 $13>$ 의 질문을 포함한 구체적인 국제개발 관련 지식에 자가 평가를 한다(DFID, 2013: 41). 
〈표 13〉ICS 성과측정 문항: 단원의 국제개발 지식 습득도

\begin{tabular}{l}
\hline \multicolumn{1}{c}{ 국제개발 지식(Knowledge) 습득 } \\
* 척도: 관련 지식이 아주 많음(a lot, 5점), 보통보다 조금 많음(above average, 4점), 보통(average, 3점), 보통 이하(below \\
average, 2점), 전혀 모름(nothing at all, 1점) \\
\hline . 선진국'과 '개발도상국' 간의 차이 \\
· 선진국의 국제개발 환동이 세계시민들과 지역사회에 미치는 영향 \\
· 개발도상국 내 성평등 문제 \\
· 세계 빈곤 및 불평등의 근본 원인 \\
· 국제개발 분야에서 봉사의 역할 \\
· 국내외 개발 분야에서 청년들의 역할 \\
· 글로벌 시민으로서의 권리 및 책임성 \\
. 개발도상국 내 불평등 문제 \\
· 국제개발 분야에서 글로벌 개발 의제(예: MDGs)의 역할 \\
\hline
\end{tabular}

출처: DFID (2013) p.41 내용을 저자가 재구성

둘째, 봉사단원의 개인적인 성향 변화를 측정하기 위해, 단원들은 아래 <표 $14>$ 의 구체적 질문들에 척도를 정하는 방식으로 자가 평가를 한다(DFID, 2013: 42).

\section{〈표 14〉ICS 성과측정 문항: 단원의 개인적인 성향 (인성) 변화}

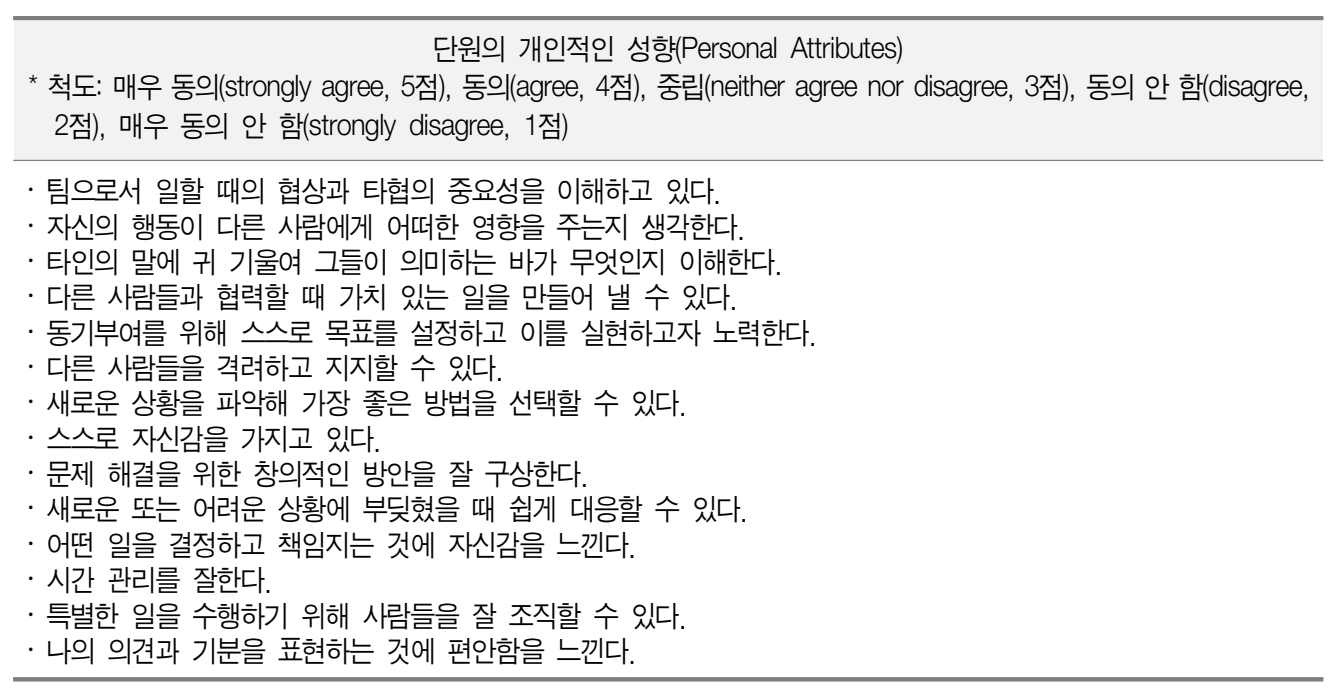

출처: DFID (2013) p.42 내용을 저자가 재구성

셋째, 단원들의 태도 변화를 측정하기 위해 아래 <표 $15>$ 의 태도 관련 질문들에 자가 평가를 한다(DFID, 2013: 43). 


\section{〈표 15〉ICS 성과측정 문항: 단원들의 태도 변화}

\section{단워들의 태도(Attitudinal Statements)}

* 척도: 매우 동의(strongly agree, 5점), 동의(agree, 4점), 중립(neither agree nor disagree, 3점), 동의 안 함(disagree, 2점), 매우 동의 안 함(strongly disagree, 1점)

· 다른 배경을 가진 사람들로부터 새로운 것을 배우기 좋아한다.

· 다른 사람들을 돕고 변화를 일으키는 일에 대한 열정이 있다.

· 모든 사람은 세계 불평등의 문제를 해결하기 위해 마땅히 노력해야 한다.

- 나는 어떠한 배경에도 상관없이 모든 사람을 똑같이 대한다.

- 다문화 환경에서 일할 때 의사소통 방법을 조정하는 것이 중요하다고 생각한다.

· 봉사 사업은 세계 곳곳의 빈곤 문제를 다루는 데 도움을 준다.

- 문화에 따라 나타나는 행동 양식은 매우 다양하지만 모두 마땅히 존중받아야 한다.

- 다양한 문화의 사람들로 이루어진 공동체는 모든 사람에게 좋은 영향을 미친다.

· 개인의 문화적 배경은 가치관 및 행동 양식에 영향을 미친다고 생각한다.

- 자신이 생각하는 것과 다른 사람이 바라본 내 모습이 때때로 다르다고 생각한다.

- 때로 어떤 사람들의 행동에 동의하지는 않지만 그들의 관점을 이해하려고 노력한다.

· 내 행동이 세계 빈곤 문제를 해결하는 일에 도움을 준다고 생각한다.

- 다른 배경을 가진 사람들과 교류하는 것에 자신 있다.

· 다른 사람에 동의하지 않더라도 기꺼이 그들의 관점을 받아들인다.

· 사람들의 빈곤은 그들의 잘못이 아니다.

출처: DFID (2013) p.43 내용을 저자가 재구성

넷째, 단원의 구체적인 기술 습득과 관련된 성과를 측정하기 위해, 아래 <표 $16>$ 의 태도 관련 질문에 척도를 정한다.

\section{〈표 16〉ICS 성과측정 문항: 단원의 구체적인 기술 습득}

단원의 구체적인 기술 습득(Specific Skills)

* 척도: 매우 동의(strongly agree, 5점), 동의(agree, 4점), 중립(neither agree nor disagree, 3점), 동의 안 함(disagree, 2점), 매우 동의 안 함(strongly disagree, 1점)

· 활동 수행을 위한 계획의 중요성을 잘 이해하고 있다.

· 개발 이슈에 대한 인식 향상에 기여할 수 있다.

- 지역사회에 대한 자문 및 사람들의 필요 - 수요를 파악하는 역량을 향상했다.

· 활동을 조직하고 관리하는 능력을 향상했다.

· 모든 사람의 의견을 고려해 그룹 토의를 잘 이끌 수 있다.

- 내 생각을 다른 사람들과 공유할 수 있다.

· 외국어 능력이 향상되었다.

- 기금을 마련하는 역량을 개발했다.

- 예산을 관리하는 역량을 개발했다.

출처: DFID (2013) p.49 내용을 저자가 재구성

\section{2) 수원국 측면 결과(In-Country Outcomes)}

봉사단원 활동이 수원국에 미치는 구체적인 영향을 측정하기 위해, 아래 <표 $17>$ 질문에 수혜 기관 및 개발도상국 관련자들이 척도를 정해 평가한다. 
〈표 17〉ICS 성과측정 문항: 수원국 측면성과

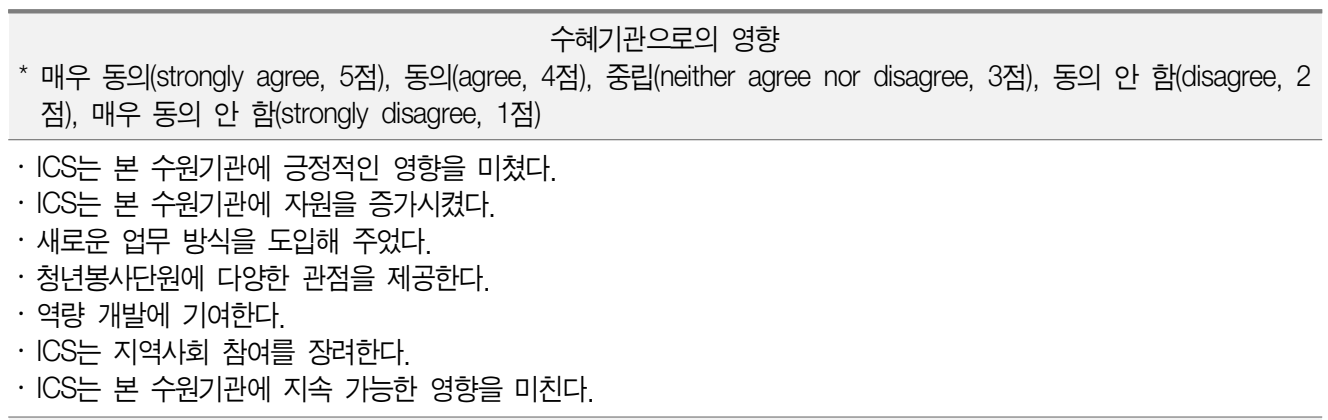

ICS 봉사사업 참여 경험

* 매우 동의(strongly agree, 5점), 동의(agree, 4점), 중립(neither agree nor disagree, 3점), 동의 안 함(disagree, 2 점), 매우 동의 안 함(strongly disagree, 1점)

- 봉사단원에게 파견 전 적절한 훈련 및 관련 정보를 제공했다.

· 본 수원기관은 ICS 관련 정보 및 달성 목표에 대한 이야기를 자세히 들을 수 있었다.

· 파견 착수를 위해 기관의 요구 사항을 영국으로부터 지원받았다.

· 봉사단원 도착 전에 필요한 세부 사항을 제공받았다.

· 봉사단원의 파견 기간 동안 필요한 부분을 지원받았다.

ICS 사업이 수원국 지역사회에 미치는 영향

* 매우 동의(strongly agree, 5점), 동의(agree, 4점), 중립(neither agree nor disagree, 3점), 동의 안 함(disagree, 2 점), 매우 동의 안 함(strongly disagree, 1점)

· ICS는 지역사회에 긍정적인 영향을 미친다.

- 지역사회가 새로운 기술을 발전시킬 수 있도록 한다.

- 지역사회 개발에 대한 주민들의 참여적 지원을 이끈다.

- 주민들이 지역사회 의사 결정 과정에 적극 참여하도록 돕는다.

· 현지 봉사 활동이 더욱 활발해지도록 한다.

· 지역사회의 권한을 강화한다.

- 지역사회 내 취약 계층에 대한 옹호 활동을 강화한다.

- 기초교육 이수 비율을 증가한다.

· 보건 서비스 활용 비율을 장려한다.

- 새로운 학습과정 이수를 장려한다.

- 새로운 기업 및 일자리 창출을 지원한다.

· 성 - 생식 건강 서비스 활용을 증가한다.

· 더욱 안전하고 효과적인 위생 습관을 장려한다.

- 자연환경 및 자원 관리를 개선한다.

- 지역사회 내 청년의 긍정적 가치관 형성에 영향을 준다.

ICS 봉사단원들의 기여에 대한 의견

* 매우 동의(strongly agree, 5점), 동의(agree, 4점), 중립(neither agree nor disagree, 3점), 동의 안 함(disagree, 2 점), 매우 동의 안 함(strongly disagree, 1점)

- ICS 단원은 지역사회에 성공적으로 개입한다.

- ICS 단원의 기여는 지역사회 개발에 가치가 있다.

- 파견 봉사단원은 새로운 기술을 개발한다.

· 봉사 활동을 통해 빈곤, 평등, 개발에 대한 이해가 증가한다.

· 봉사 활동을 통해 타 문화에 대한 이해가 증가한다.

- ICS 단원은 봉사 활동을 통해 의미 있는 기여를 할 수 있다.

- ICS 봉사단원과 다시 일할 마음이 있다.

출처: DFID (2013) pp.49 59 내용을 저자가 재구성 


\section{IV. 호주 국제개발봉사프로그램(AVID)}

\section{1. 개요 및 논리모형}

호주 정부는 2011년 호주 국제개발봉사프로그램(Australian Volunteers for International Development, 이하 AVID)을 발족했으며, 발족 당시 AVID는 오스트레이닝 인터내셔널 (Austraining International), 호주적십자사(Australian Red Cross), 호주국제자원봉사단 (Australian Volunteers International, 이하 AVI), 호주국제개발청(Australian Aid, 이하 AusAID)을 포함해 총 4개 기관의 프로그램을 통합했다. 각 기관에 따라 차별적인 프로그램 운영 방식이 AVID라는 통합 브랜드 내에서 동일한 기획, 선발, 운영 과정으로 운영되기 시작하 면서 프로그램의 정책 및 가이드라인 개발과 프로그램 전반에 대한 관리 등을 포함한 AVID의 운영을 호주 외교통상부(Australian Government Department of Foreign Affairs and Trade, 이하 DFAT)가 담당하고 있다.

DFAT는 2014년 AVID 프로그램 평가를 실시하며, 문헌조사와 정부기관 및 파트너 기관의 다양한 이해관계자 면담을 통해 AVID 프로그램 성과모형을 구축한 바 있다. (아래 <표 18> 참조)

\section{〈표 18〉 AVID의 해외봉사사업 논리모형}

\begin{tabular}{|c|c|c|}
\hline \multicolumn{2}{|r|}{ 장기적 성과 } & \multirow{8}{*}{$\begin{array}{l}\text { 기타 영향 요소 } \\
\text { · 경제적 · 사회적 · 정치적 } \\
\text { 압력 } \\
\cdot \text { 호주 정부의 정책 및 태도 } \\
\text { 변화 } \\
\text { 새로운 기회와 위기 }\end{array}$} \\
\hline $\begin{array}{l}\mathrm{AVID} \text { 가 목표하는 결과의 } \\
\text { 점진적 달성 }\end{array}$ & $\begin{array}{l}\cdot \text { 호주 정부와 수원국의 개발 목표 } \\
\cdot \text { 호주에 대한 긍정적인 국제적 인지도 } \\
\cdot \text { 해외봉사 사업에 대한 호주 내 지원 향상 }\end{array}$ & \\
\hline 수원기관 측면 & - 수원국의 국가 개발에 기여 & \\
\hline 봉사단원 측면 & · 호주 원조 사업의 옹호에 기여 & \\
\hline \multicolumn{2}{|r|}{ 중기적 성과 } & \\
\hline 수원국 측면 영향 & $\begin{array}{l}\text { · 수원기관의 역량 및 지속 가능한 역량 향상 } \\
\text { · 호주의 인지도 개선 }\end{array}$ & \\
\hline 봉사단원 측면 영향 & $\begin{array}{l}\text { · 봉사단원의 개인적 - 전문적 발전 } \\
\text { - 개발에 대한 이해도 및 긍정적 이해 향상 }\end{array}$ & \\
\hline 봉사단원의 효과적 활동 & $\begin{array}{l}\cdot \text { 봉사활동 업무목표 달성 } \\
\text { 수혜기관의 만족 } \\
\cdot \text { 봉사단원의 만족 } \\
\text { 위험에 대한 효과적 관리 }\end{array}$ & \\
\hline
\end{tabular}




\begin{tabular}{|c|c|c|}
\hline \multicolumn{2}{|r|}{ 단기적 결과 } & \\
\hline $\begin{array}{l}\text { 봉사단원의 적절한 업무 } \\
\text { 활동 }\end{array}$ & $\begin{array}{l}\text { · 수원기관에게 적합한 활동 수행 } \\
\text { · 단원에게 적합한 활동 수행 } \\
\text { 수원기관 역량 강화 및 지속적 역량 강화 } \\
\text { · AVID의 목표와 일치한 활동 수행 } \\
\text { · 위험에 대한 실질적 관리 }\end{array}$ & \\
\hline 수원기관 측면 & · 적합한 수원기관의 선정 및 준비 & \\
\hline 단원 측면 & · 적합한 단원의 선발 및 준비 & \\
\hline 파견 기관 측면 & - AVID의 정책 환경, 파트너십 방식, 행정 체계의 적합성 & \\
\hline
\end{tabular}

출처: DFAT (2014) p.21 내용을 저자가 재구성

예를 들어, 위 <표 18>에서 명시한 중기적 성과 중 하나인 수원기관의 역량은 역량(capacity), 지속 가능한 역량(sustainable capacity) 그리고 역량 개발(capacity development) 방면에서 성과가 측정된다. 동 성과는 만족도(satisfaction) 설문조사 형식으로 평가되고 있으며, 다양한 문항에 응답자들이 만족도를 체크하도록 되어 있다(DFAT, 2014: 42). 몇 가지 문항 예시는 아래 <표 19>에서 명시하고 있다.

\section{〈표 19〉AVID 수혜기관의 역량개선 성과 관련 만족도 설문 문항 예시}

척도 : 1점부터 5점까지, '매우 불만족(very dissatisfied, 1점)' 혹은 '매우 동의하지 않음(strongly disagree, 1점)'부터 '매우 만족(very satisfied, 5점)' 혹은 '매우 동의함(strongly agree, 5점)'까지

\begin{tabular}{|c|c|}
\hline $\begin{array}{c}\text { 현지 기관의 역량(Capacity) } \\
\text { 개선에 대한 평가 }\end{array}$ & $\begin{array}{l}\text { AVID 단원은 우리 팀과 협력적으로 일을 수행한다. } \\
\text { AVID 단원의 도움은 우리 조직의 프로그램 전달과 목적 달성에 도움이 되었다. } \\
\text { AVID 단원이 수행한 일은 현지에 있는 직원이 더 효과적으로 수행할 수 있었을 것이다. }\end{array}$ \\
\hline $\begin{array}{l}\text { 현지 기관의 역량의 } \\
\text { 지속성(Sustained Capacity) } \\
\quad \text { 개선에 대한 평가 }\end{array}$ & $\begin{array}{l}\text { 봏사단원의 과업이 종료된 이후에도 우리 현지 기관은 혜택을 받고 있다. } \\
\text { 현지 기관 직원들이 새로운 기술을 배우는 데 있어서 봉사단원들이 도움을 주었다. } \\
\text { 봉사단원들이 떠난 후에도 그들로부터 소식을 듣고 있다. }\end{array}$ \\
\hline $\begin{array}{l}\text { 현지 기관의 역량 개발 } \\
\text { (Capacity Development) } \\
\quad \text { 개선에 대한 평가 }\end{array}$ & $\begin{array}{l}\text { 봉사단원을 수혜하는 것은(hosting volunteers) 우리 조직의 업무가 어떻게 향상하면 좋을지 } \\
\text { 생각하는 계기가 되었다. } \\
\text { 우리 조직은 단원의 인력 활용에 있어 장기적 전략을 보유한다. } \\
\text { 단원을 수혜하는 것은 우리 조직의 업무를 우리 스로 더 잘 처리하는 데 도움을 주었다. } \\
\text { 봉사단원을 수혜하는 것은 우리 조직의 목표와 전략을 명환히 하는 데 도움을 주었다. } \\
\text { 봉사단원을 수혜하는 것은 지역사회에서 우리 조직의 위상을 높이는 데 도움이 되었다. } \\
\text { 봉사단원을 수혜하는 것은 우리 조직의 서비스를 이용하는 사람들의 경험을 더 잘 이해하는 } \\
\text { 데 도움이 되었다. }\end{array}$ \\
\hline
\end{tabular}

출처: DFAT (2014) pp.43 6 내용을 저자가 재구성

위 <표 19>에서 보여 주는 역량 관련 평가 이외에도, 현지 기관의 AVID 프로그램에 대한 전반적 만족도는 (1) 호주 봉사단원에 대해 얼마나 만족하는지, (2) 파트너 기관(공여 기관)으로부터 받은 지원을 얼마나 만족하는지에 대한 문항에 응답하는 것으로 평가된다(DFAT, 2014: 43). 


\section{3. 평가 문항}

2014년에 호주 AVID가 실행한 평가는 (1) 호주의 개발 사업을 수행하는 데 있어 봉사단원의 기여 확인, (2) 해외봉사 사업의 효과성과 효율성에 긍정적·부정적인 영향을 미친 내적·외적 요소 발견, (3) 해외봉사 사업의 디자인과 관리에 있어 제언 도출을 그 목적으로 했다. 상기 3 개 목적을 달성하기 위한 중점 평가 문항은 4 가지로 나눌 수 있으며, 세부 문항은 아래<표 $20>$ 과 같다.

〈표 20〉AVID 평가 중점 세부 문항 및 근거 자료 예시

연계성: 호주 원조 프로그램의 목적을 달성하기 위해 봉사단원이 활동할 수 있도록 분명하고 일관적인 전략으로 진행하고 있는가?

\begin{tabular}{|c|c|c|}
\hline & 평가 중점 질문 & 근거 자료 출처 \\
\hline 질문 1 & $\begin{array}{l}\text { 봉사단원 파견 시 호주 원조 프로그램 및 AusAID의 국가 협력 전략의 } \\
\text { 우선순위를 어느 정도 고려한 것인가? }\end{array}$ & 봉사단원 업무 계획 \\
\hline 질문 2 & $\begin{array}{l}\text { 봉사단원의 파견은 핵심 파트너와 AusAID의 자문을 반영한 수원기관 } \\
\text { 의 장기 전략에 따라 이루어지는가? }\end{array}$ & $\begin{array}{l}\text { 수원기관 · 핵심 파트너·AusAID 인 } \\
\text { 터뷰 }\end{array}$ \\
\hline 질문 3 & $\begin{array}{l}\text { 봉사단원을 파견할 때 AusAID 직원이 수원 기관의 확인 및 승인 절차 } \\
\text { 에 관여하는가? 또한 국가 협력 전략의 우선순위를 반영하고자 노력하 } \\
\text { 는가? }\end{array}$ & $\begin{array}{l}\text { 봉사단원의 업무 계획, AusAID의 인 } \\
\text { 터뷰, 사업 디자인 비교 문서, 핵심파 } \\
\text { 트너 인터뷰 }\end{array}$ \\
\hline 질문 4 & $\begin{array}{l}\text { 업무 내용이 공급(supply)보다는 수요 위주(demand)로 이루어지는가? } \\
\text { 현지 직원의 잠재적 이동이나 상호 원조 및 자립의 변질 위험이 존재 } \\
\text { 하는가? 혹은 수원기관의 의존을 고려하고 효과적으로 관리하고 있는 } \\
\text { 가? }\end{array}$ & $\begin{array}{l}\text { 수원 기관 인터뷰, 수원 기관 설문조 } \\
\text { 사, 핵심 파트너 및 인터뷰 }\end{array}$ \\
\hline 질문 5 & $\begin{array}{l}\text { 비용면에서 봉사단원의 파견과 기술 지원은 어떤 차이가 있는가? 다른 } \\
\text { 기술 지원과 비교했을 때 봉사단원 파견의 상대적인 장점 및 약점은 } \\
\text { 무엇인가? 또한 이러한 부분은 AusAID 원조 프로그램의 봉사단원 활 } \\
\text { 용 전략 및 접근법에 일반적으로 고려되고 있는가? }\end{array}$ & $\begin{array}{l}\text { AusAID 인터뷰, 문헌 자료 검토, 봉 } \\
\text { 사단원 비용 데이터 }\end{array}$ \\
\hline 질문 6 & $\begin{array}{l}\text { AVID 프로그램의 봉사단원 파견에 대한 협력적인 접근법을 위한 } \\
\text { AusAID-기타 봉사 제공 기관 사이의 효과적인 연계 방안은 무엇인가? }\end{array}$ & $\begin{array}{l}\text { 핵심 파트너 및 ICM 인터뷰, 이전 } \\
\text { AusAID 인터뷰 }\end{array}$ \\
\hline 질문 7 & $\begin{array}{l}\text { Australian Youth Ambassadors for Development (AYAD) 사업이 } \\
\text { AVID 사업과 적절하게 연관되어 이어질 수 있는가? }\end{array}$ & $\begin{array}{l}\text { 귀국 봉사단 설문조사, 핵심 파트너 } \\
\text { 인터뷰, AusAID 인터뷰, 대사(외교 } \\
\text { 관) 또는 전 AusAID의 인터뷰 }\end{array}$ \\
\hline \multicolumn{3}{|c|}{ 정책 및 행정: 관련 정책은 일관성 있게 AVID 수행을 지원하며, 프로그램의 목표 달성에 기여하고 있는가? } \\
\hline 질문 8 & $\begin{array}{l}\text { 이해관계자들이 AVID의 목표를 분명하게 인식하고 있는가? AVID를 } \\
\text { 위한 정책 및 행정 준비가 타당한가? 또한 관련 목표를 달성하기 위해 } \\
\text { 프로그램을 지원하고 있는가? }\end{array}$ & 정책 문서 분석, 핵심 파트너 인터뷰 \\
\hline 질문 9 & $\begin{array}{l}\text { 이해관계자들이 서로 기준을 공유하고 있는가? AVID 관리를 위한 파 } \\
\text { 트너 기반의 유연한 접근을 유지하면서 공통 기준을 위해 서로 필요 } \\
\text { 사항 조정하는 방법은 무엇인가? }\end{array}$ & $\begin{array}{l}\text { 핵심 파트너 인터뷰, AusAID 인터뷰, } \\
\text { 모니터링 및 평가 기준 검토 }\end{array}$ \\
\hline
\end{tabular}




\begin{tabular}{|c|c|c|}
\hline 질문 10 & $\begin{array}{l}\text { 수원 기관의 역량 강화 및 개발 성과에 기여하기 위한 봉사단원(개인 } \\
\text { 및 집단 모두)의 효율성 제고와 관련해 분명한 정책 및 절차가 존재하 } \\
\text { 는가? 봉사단원의 기간(단기 혹은 장기), 파견 지역(종류, 집중 분야)의 } \\
\text { 모든 업무에서 균현 유지 등과 같은 다양한 종류의 업무 관련 사항의 } \\
\text { 우열에 관한 적절한 고려가 이루어졌는가? }\end{array}$ & $\begin{array}{l}\text { 핵심 파트너 인터뷰, 봉사단원 인터 } \\
\text { 뷰 }\end{array}$ \\
\hline 질문 11 & $\begin{array}{l}\text { 수원 기관과의 교류는 시간이 지나도 여전히 효과적이고 지속 가능한 } \\
\text { 가? 협력한 수원기관이 얻은 경험은 무엇인가? }\end{array}$ & $\begin{array}{l}\text { 핵심 파트너 인터뷰, 수원 기관 설문 } \\
\text { 조사, 귀국봉사단원 설문조사 }\end{array}$ \\
\hline 질문 12 & $\begin{array}{l}\text { 선발 정책 및 절차는 수원 기관 및 현지 문화를 고려해 기술, 경험, } \\
\text { 개인적 성품 면에서 적합한 봉사단원을 모집하는가? 봉사단원의 다양 } \\
\text { 성 환대가 성, 불평등, 포괄적 개발, 화합, 프로그램 목표 홍보와 관련 } \\
\text { 한 AusAID 정책에 맞게 이루어지고 있는가? }\end{array}$ & $\begin{array}{l}\text { 수원 기관 인터뷰, 수원 기관 설문조 } \\
\text { 사, 귀국 봉사단원 설문조사 }\end{array}$ \\
\hline 질문 13 & $\begin{array}{l}\text { 봉사단원 프로그램은 호주에 대한 이해 수준, 다른 문화에 대한 개방성, } \\
\text { 가치관 및 관점, 개발 협력에 대한 대중의 지지를 향상하기 위한 수단으 } \\
\text { 로써 전략적이고 일관된 접근법을 구축하고 있는가? }\end{array}$ & $\begin{array}{l}\text { 미디어 분석(AVID 소통전략 포함), 다 } \\
\text { 사(외교관) 인터뷰 }\end{array}$ \\
\hline 질문 14 & $\begin{array}{l}\mathrm{AVID} \text { 를 통해 과거 프로그램의 단점을 보완하고 프로그램 및 브랜드의 } \\
\text { 단일성을 향상했다는 근거가 있는가? }\end{array}$ & $\begin{array}{l}\text { 미디어 분석, 핵심 파트너 인터뷰, 수 } \\
\text { 원 기관 인터뷰 }\end{array}$ \\
\hline \multicolumn{3}{|c|}{ 활동 관리: AusAID 프로그램의 모니터링 및 관리가 제대로 이루어지고 있는가? } \\
\hline 질문 15 & $\begin{array}{l}\text { 봉사단원의 여러 파견 지역 및 분야에 따른 다양한 활동 내용을 비교 } \\
\text { 하기 위한 모니터링 및 평가 접근법이 일관성 있게 수행되고 있는가? }\end{array}$ & $\begin{array}{l}\text { 모니터링 및 평가 기준 검토, 계획 및 } \\
\text { 모니터링 데이터, 핵심 파트너 인터 } \\
\text { 뷰, 수원 기관 인터뷰 }\end{array}$ \\
\hline 질문 16 & $\begin{array}{l}\text { 프로그램의 결함을 파악하고, 활동 내용을 향상하기 위해 관련 데이터 } \\
\text { 를 모니터링하고 검토하는 타당한 접근법을 마련했는가? }\end{array}$ & $\begin{array}{l}\text { 모니터링 및 평가 기준 검토, 계획 및 } \\
\text { 모니터링 데이터, 핵심 파트너 인터 } \\
\text { 뷰, 수원 기관 인터뷰 }\end{array}$ \\
\hline \multicolumn{3}{|c|}{ 효과: 호주 개발 성과를 위해 봉사단원은 어떤 기여를 했는가? } \\
\hline 질문 17 & $\begin{array}{l}\text { 봉사단원의 활동이 개인 · 기관 - 지역사회의 개발 성과를 달성하는 데 } \\
\text { 기여하고 있는가? 수원 기관의 역량 강화를 위한 봉사단원의 기여도는 } \\
\text { 어느 정도인가? 봉사단원을 통한 수원 기관의 장단기적 수혜는 무엇인 } \\
\text { 가? 이러한 수혜는 봉사단원의 활동이 끝난 후에도 지속적으로 유지될 } \\
\text { 수 있는가? }\end{array}$ & $\begin{array}{l}\text { 귀국 봉사단원 설문조사, 수원 기곤 } \\
\text { 설문조사, 수원 기관 인터뷰, 봉사든 } \\
\text { 원 인터뷰, 활동 종료 보고서 분석 }\end{array}$ \\
\hline 질문 18 & $\begin{array}{l}\text { 봉사단원으로서의 경험 및 상호 교류가 국제개발 분야의 정책과 관습 } \\
\text { 을 개선하는 데 도움을 주는가? 봉사단원은 호주와 협력국의 다양한 } \\
\text { 기관 및 지역사회 간의 파트너십을 지속적으로 개발하는 역할을 담당 } \\
\text { 하는가? 사람-사람 간의 관계 형성과 유지에 봉사단원은 어느 정도 } \\
\text { 기여하는가? }\end{array}$ & $\begin{array}{l}\text { 귀국 봉사단원 설문조사, 수원 기관 } \\
\text { 설문조사, 수원 기관 인터뷰, 봉사든 } \\
\text { 원 인터뷰, 활동 종료 보고서 분석 }\end{array}$ \\
\hline 질문 19 & $\begin{array}{l}\text { AVID가 공공 외교(글로벌 시민 및 봉사 활동에 대한 긍정적 이미지 } \\
\text { 배양)에 어느 정도까지 기여하고 있는가? AusAID는 원조의 중요성을 } \\
\text { 알리고 국제사회의 빈곤을 감소시키는 역할을 효과적으로 수행하고 } \\
\text { 있는가? }\end{array}$ & $\begin{array}{l}\text { 미디어 분석, 봉사단원 분야 시장조 } \\
\text { 사 및 데이터 분석 }\end{array}$ \\
\hline 질문 20 & $\begin{array}{l}\mathrm{AVID} \text { 의 봉사 활동이 다양한 봉사단원들의 자기계발 및 전문성 향상에 } \\
\text { 영향을 주었는가? }\end{array}$ & $\begin{array}{l}\text { 귀국 봉사단원 설문조사, 봉사단운 } \\
\text { 인터뷰, 활동 종료 보고서 분석 }\end{array}$ \\
\hline
\end{tabular}

출처: DFAT (2014) pp.76 9 내용을 저자가 재구성 


\section{V. 한국 월드프렌즈코리아(WFK)4)}

\section{1. 개요}

한국국제협력단(Korea International Cooperation, 이하 KOICA)은 1990년에 44명의 해 외 봉사단을 파견한 이후, '해외 봉사단 파견을 통한 개발도상국 주민의 삶의 질 향상'이라는 사업 목적에 초점을 맞춰 2017년 현재까지 28년간 해외 봉사단 사업을 추진해 왔다. 2011년부 터 정부 파견 해외 봉사단이 월드프렌즈코리아(World Friends Korea, 이하 WFK)라는 단일 브랜드로 통합되면서 $\mathrm{KOICA}$ 는 WFK 사업의 총괄 시행 기관으로서 사업 계획, 예산, 성과 관리 등을 통합 추진 중이다.

2017년에 출범한 문재인 정부는 일자리 창출을 최우선 국정 과제로 추진하고 있으며, 2017년 6 월에 $\mathrm{KOICA}$ 는 ‘국제개발협력 분야 글로벌 인재 양성 및 양질의 일자리 창출 기본 계획’을 자체적으로 수립했다. 동 계획은 사업 참여의 기회 제공, 사전·사후 교육, 경력 개발 컨설팅을 골자로 해외 봉사, 민관 협력, 국별 협력 사업, ODA 교육 등 다양한 사업 수단을 망라하고 있다. KOICA는 상기 계획을 이행하기 위해 2017년 ODA청년인턴 사업을 월드프렌즈 본부로 이관하면서 월드프렌즈 소관 사업 명을 '해외 봉사단'에서 '해외 봉사단 및 국제개발협력 인재 양성’으로 변경했다. 그러나 현재 ‘해외 봉사단 파견을 통한 개발도상국 주민의 삶의 질 향상'이 라는 본부의 기존 사업 목적 및 범위를 중심으로 청년인턴 파견 업무가 단순히 추가되어 있는 실정이다. 따라서 현재 $\mathrm{KOICA}$ 사업 전반에 참여하는 다양한 유형의 글로벌 인재 양성 및 양질의 일자리 창출이라는 사업 목표를 달성하기 위해서는 전담 조직 신설 및 컨트롤타워 기능 부여 등이 필요한 시점이라고 할 수 있다.

‘국제개발협력 분야 글로벌 인재 양성 및 양질의 일자리 창출 기본 계획’이 이미 수립된 점, 향후 별도의 전담 조직을 통해 이행될 점 등을 감안해, 본고에서 논하는 $\mathrm{WFK}$ 중기 성과 체계의 범위는 '해외 봉사단 및 국제개발협력 인재 양성' 사업 중 해외봉사 사업만을 대상으로 한다. WFK봉사단 사업은 $\mathrm{KOICA}$ 봉사단, IT 봉사단, 청년봉사단, 과학기술지원단, 자문단으로 세부 분류된다.

4) 동 절은 한국국제협력단(2017a) 'WFK 중기성과 체계 및 추진 전략(2018 2022)'(내부 자료)을 참고해 요약 작성한 것이다. 


\section{2. 성과모형 및 지표}

$\mathrm{KOICA}$ 는 WFK 성과 체계의 고도화 및 측정지표 수립을 위해 많은 연구를 수행한 바 있으며,5) WFK 사업에 적절한 성과모형과 지표 수립을 위해 지속적인 노력을 기울이고 있다. 현재 WFK 사업부는 3대 전략목표 달성을 위해 9개의 중기 과제(2018 2022)를 추진 중이며, 과제 추진을 위한 지표 수립 작업을 진행하고 있다. (아래 <표 21> 참고)

\section{〈표 21〉 WFK 전략목표, 중기 추진 과제, 활동 및 지표(안)}

\begin{tabular}{|c|c|c|}
\hline 전략목표 & 중기추진과제 & 주요 활동 및 중기성과지표 예시(안) \\
\hline \multirow{5}{*}{$\begin{array}{l}\text { 목표 } 1 . \\
\text { 개발도상국 현장 } \\
\text { 에서 개발 성과 }\end{array}$} & $\begin{array}{l}\text { 과제 } 1 . \\
\text { SDGs 달성지원 }\end{array}$ & 미정(지표 세분화 중) \\
\hline & \multirow{4}{*}{$\begin{array}{l}\text { 과제 } 2 . \\
\text { 수원국 역량 강화 }\end{array}$} & $\begin{array}{l}\text { 지표 2-1. 협력 기관에 역량 강화 교육을 제공한 실적 달성도 - 협력 기관을 } \\
\text { 대상으로 역량 강화 교육 활동을 실시한 봉사단원 1인당 협력 기관 } \\
\text { (또는 유관 기관) 관계자 교육 목표(1회 이상 교육을 받은 관계자 } \\
\text { 수)에 대한 달성도 } \\
\text { · 지표 유형 및 측정 주기: 단일지표, 계량지표 / 6개월 } \\
\text { - 활용 데이터: 봉사활동보고서, 협력기관 반기보고 } \\
\text { · 수집 주체: 봉사단원, co-worker } \\
\text { - 측정 방법: 자가 기입, 제 } 3 \text { 자 확인 } \\
\text { - 측정산식: 가중치, 관련 활동을 실시한 봉사단원 수, 봉사단원 교육 제공 } \\
\text { 실적 및 목표치를 고려해 계산 }\end{array}$ \\
\hline & & $\begin{array}{l}\text { 지표 2-2. 협력 기관에 기자재 또는 교보재의 제공 실적 달성도 - 기자재 } \\
\text { 또는 교보재 제공 활동을 실시한 봉사단원 1인당 제공 목표(기자재 } \\
\text { 및 교보재 수) 대비 제공 실적을 측정 } \\
\text { - 지표 유형 및 측정 주기: 단일지표, 계량지표 / } 6 \text { 개월 } \\
\text { - 활용 데이터: 봉사활동보고서, 협력기관 반기보고 } \\
\text { - 수집 주체: 봉사단원, co-worker } \\
\text { - 측정 방법: 자가 기입, 제3자 확인 } \\
\text { - 측정산식: 가중치, 관련 활동을 실시한 봉사단원 수, 봉사단원의 기자재 } \\
\text { 및 교보재 실적과 목표치를 고려해 계산 }\end{array}$ \\
\hline & & $\begin{array}{l}\text { 지표 2-3. 협력 기관에 컨설팅 제공 실적 달성도 - 협력 기관(또는 유관 기관)에 } \\
\text { 컨설팅을 제공한 실적을 측정 } \\
\text { · 지표 유형 및 측정 주기: 단일지표, 계량지표 / 6개월 } \\
\text { · 활용 데이터: 봉사활동보고서, 협력기관 반기보고 } \\
\text { · 수집 주체: 봉사단원, co-worker } \\
\text { · 측정 방법: 자가 기입, 제3자 확인 } \\
\text { · 측정산식: 가중치, 관련 활동을 실시한 봉사단원 수, 봉사단원의 컨설팅 } \\
\text { 제공 실적과 목표치를 산식에 대입해 계산 }\end{array}$ \\
\hline & & $\begin{array}{r}\text { 지표 2-4. 협력 기관과 관련해 연구보고서 제출 실적 달성도 - 협력 기관(또는 } \\
\text { 유관 기관)과 관련된 연구보고서를 작성해 제출한 봉사단원 1인당 }\end{array}$ \\
\hline
\end{tabular}

5) 홍문숙 외(2016, 2017), 이태주 외(2016), 구영은 외(2016, 2017) 등을 참고하면 된다. 


\begin{tabular}{|c|c|c|}
\hline 전략목표 & 중기추진과제 & 주요 활동 및 중기성과지표 예시(안) \\
\hline & & $\begin{array}{l}\text { 제출 목표 대비 제출 실적을 측정 } \\
\text { · 지표 유형 및 측정 주기: 단일지표, 계량지표 / 6개월 } \\
\text { · 황용 데이터: 봉사ㅎㅘㅘ동보고서, 협력기관 반기보고 } \\
\text { · 수집 주체: 봉사단원, co-worker } \\
\text { · 측정 방법: 자가 기입, 제 } 3 \text { 자 확인 } \\
\text { · 측정산식: 가중치, 관련 활동을 실시한 봉사단원 수, 봉사단원의 연구보고 } \\
\text { 서 제출 실적과 목표치를 산식에 대입해 계산 }\end{array}$ \\
\hline & \multirow[t]{2}{*}{$\begin{array}{l}\text { 과제 } 3 . \\
\text { 포용적 개발 효과 }\end{array}$} & $\begin{array}{l}\text { 지표 3-1. 수혜자 중 취약 계층의 비율 - 봉사단 참여자 중 취약 계층 비율을 } \\
\text { 측정 } \\
\text { · 지표 유형 및 측정 주기: 단일지표, 계량지표 / 1년 } \\
\text { · 활용 데이터: 모집 선발 실적 } \\
\text { ·수집 주체: 글로벌인재양성실 } \\
\text { · 측정 방법: 자가 기입, 제3자 확인 }\end{array}$ \\
\hline & & 지표 3-2. 수혜자 수 \\
\hline \multirow{6}{*}{$\begin{array}{l}\text { 목표 } 2 . \\
\text { 봉사단 참여자의 } \\
\text { 성장 및 기여 }\end{array}$} & \multirow{3}{*}{$\begin{array}{l}\text { 과제 } 4 . \\
\text { 봉사단 참여기회 확대 }\end{array}$} & 지표 4-1. 직종 일치율 제고 - 만족도조사 시 봉사단 직종 일치율 제고 \\
\hline & & $\begin{array}{l}\text { 지표 4-2. 봉사단 참여자의 다양성 확대 - 연도별 봉사단 파견자 중 취약 } \\
\text { 계층 및 지방 출신 비율 확대 }\end{array}$ \\
\hline & & 지표 4-3. 봉사단 지원자 수 \\
\hline & \multirow{3}{*}{$\begin{array}{l}\text { 과제 } 5 . \\
\text { 봉사단 역량 강화 }\end{array}$} & $\begin{array}{l}\text { 지표 5-1. 봉사단 외국어 능력 향상도 - 봉사단원의 전기(前期) 대비 외국어 } \\
\text { 능력 향상 정도(봉사단원 전체 평균)를 측정 } \\
\text { · 지표 유형 및 측정 주기: 단일지표, 계량지표 / 6개월 } \\
\text { · 활용 데이터: 현지 적응 훈련기관 평가 결과 } \\
\text { · 수집 주체: 현지 적응 훈련기관 외국어 강사 } \\
\text { · 측정 방법: 시험에 따른 등급 부여 } \\
\text { · 측정산식: 외국어 능력 평가 참여한 봉시단원 수, 전기 및 당기 등급 배점을 } \\
\text { 고려해 계산 }\end{array}$ \\
\hline & & $\begin{array}{l}\text { 지표 5-2. 봉사단 역량 및 인성 향상도 - 봉사단원의 전기(前期) 대비 역량 } \\
\text { 및 인성 함양 정도(봉사단원 전체 평균)를 측정 } \\
\text { · 지표 유형 및 측정 주기: 단일지표, 계량지표 / 6개월 } \\
\text { · 활용 데이터: 단원 활동보고 시스템(안) } \\
\text { · 수집 주체: 봉사단원 } \\
\text { · 측정 방법: 자가 기입 } \\
\text { · 측정산식: 역량 요소 평가에 참여한 봉사단원 수, 역량 전기 및 당기 등급, } \\
\text { 각 역량 요소에 대한 전체 평균값 등을 활용해 계산 }\end{array}$ \\
\hline & & $\begin{array}{l}\text { 지표 5-3. 글로벌 파트너십 이행 실적 달성도 - 타국 해외봉사단 파견 기관과 } \\
\text { 의 협력 이행 실적을 평가하는 지표 } \\
\text { - 지표 유형 및 측정 주기: 단일지표, 계량지표 / 6개월 } \\
\text { · 활용 데이터 및 수집 주체: 사무소 보고 및 증빙 자료 / 사무소 } \\
\text { · 측정 밥법: 자가 기입 } \\
\text { · 측정산식: 타국 해외봉사단 파견 기관과의 협력 건수, 즉, (사무소 간 업무 } \\
\text { 협의 건수) + (사무소 간 공동 협력 건수 } \times 1.05 \text { ) (단원 간 공동 협력활동 } \\
\text { 건수 } \times 1.10)\end{array}$ \\
\hline
\end{tabular}

제 I 장

제II 장

제표장 


\begin{tabular}{|c|c|c|}
\hline 전략목표 & 중기추진과제 & 주요 활동 및 중기성과지표 예시(안) \\
\hline & & 지표 5-4. 인당 교육 시간 및 비용 \\
\hline & \multirow{2}{*}{$\begin{array}{l}\text { 과제 } 6 . \\
\text { 봉시단 안전 및 건강 지원 }\end{array}$} & 지표 6-1. 봉사단 안전 지원 만족도 \\
\hline & & 지표 6-2. 봉사단 건강 지원 만족도 \\
\hline & \multirow{4}{*}{$\begin{array}{l}\text { 과제 } 7 . \\
\text { 귀국 단원 발전 · 기여 }\end{array}$} & 지표 7-1. 귀국 단원 국내 훈련 강사 참여 비율 \\
\hline & & 지표 7-2. 귀국 단원 자원봉사 재참여 비율 \\
\hline & & $\begin{array}{l}\text { 지표 7-3. 귀국 단원 개발협력 분야 진출 비율 - 국제개발협력 분야에 진출한 } \\
\text { 귀국 봉사단원 수를 측정 } \\
\text { · 지표 유형 및 측정 주기: 단일지표, 계량지표 / 연간 } \\
\text { - 환용 데이터 및 측정 방법: WFK본부 DB / 사후정보 수집 } \\
\text { ·수집 주체: WFK본부 } \\
\text { · 측정산식: 귀국봉사단 중 국제개발협력 진출 누적 건수를 계산 }\end{array}$ \\
\hline & & 지표 7-4. 귀국 단원 취업자 수 \\
\hline \multirow{4}{*}{$\begin{array}{l}\text { 목표 } 3 . \\
\text { WFK 운영 효율화 } \\
\text { 및 성과 관리 강화 }\end{array}$} & \multirow{3}{*}{$\begin{array}{l}\text { 과제 } 8 . \\
\text { 성과관리 체계 강화 }\end{array}$} & 지표 8-1. 봉사단 자기 주도적 활동평가 체계 구축 여부 \\
\hline & & 지표 8-2. 국별 목표관리제 이행률 \\
\hline & & 지표 8-3. 파견자 수 \\
\hline & 과제 9. WFK 통합 이행 & 지표 9-1. WFK봉사단 통합 이행률 \\
\hline
\end{tabular}

출처: 한국국제협력단 (2017a) "WFK 중기 성과 체계 및 추진 전략 (2018 2022)"(내부 자료); 홍문숙 외 (2017) 내용을 저자가 재구성 


\section{VI. 종합 분석 및 결론}

앞서 구체적인 성과측정 체계의 수립에 선진적인 진척을 보이고 있는 미국, 영국, 호주의 성과관리 체계 및 구체적 지표를 집중적으로 조사했다.

미국 피스코는 1961년부터 피스코법에 의해 수립된 3대 전략목표를 현재까지도 피스코 성과 전략의 주축으로 유지하고 있다. 피스코는 바로 이점에서 2009년 비로소 단일 브랜드로 통합된 $\mathrm{WFK}$ 사업에 비해 전략의 일관성과 역사가 깊다고 할 수 있겠다. 피스코는 동 3 대 전략목표에 따른 활동 내용·사례, 11 개 세부 목표, 26 개 성과 목표와 각 목표당 명확한 성과측정 지표를 보유하고 있다. 또 모든 지표에 대한 책임자·주무부서, 협력부서, 근거 자료, 측정산식 등을 세밀히 관리하고 있다. 이외에도 피스코는 활동 분야별 지표를 설정(6개 분야 총 347 개 지표)해 성과를 측정 및 관리하는 고도의 성과 체계를 갖추고 있다.

특히, 피스코는 성과 측정을 위한 데이터의 품질과 근거 보장을 위해 다각적인 방법으로 데이터를 수집하고 있으며, 데이터의 정확성과 완성도를 철저히 관리하고 있다. 이처럼 품질 중심으로 진행되는 피스코의 성과 관리는 WFK 사업이 벤치마킹해야 하는 요소라고 할 수 있겠다. 그러나 (1) 피스코 프로그램의 예산6) 규모가 WFK 사업 예산7)보다 약 4배가 더 많다는 점, (2) 피스코의 11 개 전략목표 중 성과측정(measurement for results)이 독자적 목표로 포함되어 동 목표에 대한 성과가 꾸준히 tracking되고 있다는 점, (3) 피스코 내 연구를 담당하는 부서(Office of Strategic Information, Research, and Planning)가 성과 관련 데이터 수집 및 품질관리를 담당하고 있는 점 등을 고려할 때, 피스코가 체계적인 성과 관리를 수행하기에 유리한 환경은 현재 WFK 사업이 따라잡을 수 없는 점이기도 하다. 그렇지만 피스코와 같이 $\mathrm{WFK}$ 전략에 성과측정과 성과 관련 데이터의 체계적 수집 및 품질관리를 우선순위로 포함하는 것은 $\mathrm{WFK}$ 사업에 점진적으로나마 적용 가능한 방안일 수 있겠다.

한편, 영국 ICS의 성과 체계는 변화이론에 초점을 두고 있으며, 투입물부터 장기적 결과물 수준까지의 성과측정지표 pool을 보유하고 있고, 사업의 성과 평가 기준별 세부적 질문뿐만 아니라 데이터 수집 방법과 전략이 설정되어 있다. 특히, 이번 연구에서는 ICS의 성과 평가를 위한 지표 중에서도 한국의 WFK 사업이 중요시하는 봉사단원 측면, 개발도상국 측면의 성과측

6) 2016년 기준 약 USD 410million, 한화 기준 약 4,400억 원. 출처: Peace Corps, (2016b). Agency Financial Report. Washington, DC: Peace Corps.

7) 2016년 기준 약 1,195 억 원. 출처: 한국국제협력단, (2017b) 월드프렌즈코리아 사업의 이해(내부 자료). 성남. 한국국제 협력단. 
정을 위한 구체적 측정 문항을 살펴보았다.

ICS는 18 25세 청년 단원들 중심이라는 점, 봉사 기간이 10 12주로 단기간이라는 점(ICS, 2014)이 WFK 사업 중 청년봉사단의 성과지표로 활용할 수 있는 여지가 많을 것이다. 예를 들어, ICS가 단원들을 대상으로 측정하고 있는 자가 평가-지표 문항 중 단원의 국제개발 지식 습득도, 단원의 인성 및 태도 변화, 단원이 구체적 기술 습득을 측정하는 문항들은 WFK의 통합만족도조사(2016a, 2016b)에 이미 활용되고 있는 국제개발협력 지식 향상, 전문 분야 또는 관심 분야에 대한 지식·기술 향상을 측정하는 문항과 겹치며, WFK 지표(안)에 포함된 봉사단 의 역량 및 인성 향상과도 연계된다. 따라서 WFK 사업에서 동 지표들을 구체화하고 문항-측정 산식을 수립할 때 ICS의 사례를 벤치마킹할 수 있는 여지가 많을 것이다.

한편, 호주 AVI를 봉사단 사업 시행 기관으로 포함하고 있는 AVID는 2014년 문헌조사와 이해관계자 면담을 통해 AVID 프로그램 성과모형을 구축한 바 있다. AVID의 성과 체계는 앞서 살펴본 ICS와 마찬가지로 논리모형을 기반으로 하고 있으며, 수혜 기관의 역량 개선에 관한 성과 등은 만족도 설문조사 형식으로 평가하기도 한다. 특히, $\mathrm{AVID}$ 는 사업 평가 시 중점 세부 문항 20 개와 측정 데이터 출처를 세부적으로 설정하고 있는 점을 고려할 때, WFK의 사업 평가에 벤치마킹할 수 있는 여지가 많은 것으로 보인다.

한국 $\mathrm{WFK}$ 은 피스코, $\mathrm{ICS}, \mathrm{AVID}$ 와 마찬가지로 사업에 적절한 성과모형과 지표 수립을 위해 지속적인 연구와 실무적 노력을 기울이고 있다. 현재 WFK 사업부는 3대 전략목표 달성을 위해 9개의 중기 과제(2018 2022)를 및 지표 수립 작업을 진행하고 있다. 그러나 현재 제시된 $\mathrm{WFK}$ 의 성과지표는 다소 구체적이지 않고 또 측정산식이 난해한 점을 고려할 때 지속적인 모니터링과 측정이 어려울 수 있기 때문에 WFK 사업에 실제적 적용 가능성이 검증되어야 하는 단계에 있다고 할 수 있다. 예를 들어, 아래 <표 22>를 통해 피스코와 WFK 간에 중복된 는 지표(수혜자 역량 강화, 언어 습득 향상)의 산식을 비교할 수 있다.

\section{〈표 22〉 피스코와 WFK 간 지표의 측정산식 비교 예시}

\begin{tabular}{|c|c|c|}
\hline 측정 분야 & 피스코 지표 및 산식 & WFK 지표 및 산식 \\
\hline $\begin{array}{l}\text { 수혜자 역량 } \\
\text { 강화 }\end{array}$ & $\begin{array}{l}\text { 3.2: 지역 역량 강화 - 현지 주민 역량강화 사업 } \\
\text { 비율 증대(2018년까지 역량 강화를 보고 } \\
\text { 한 파트너(동료) 비율을 } 90 \% \text { 까지 확대) } \\
\text { · 측정산식 : 무작위로 선정해 인터뷰에 응 } \\
\text { 답한 파트너(동료) 중 역량 강화 또는 혁신 } \\
\text { 을 보고한 비율 }\end{array}$ & \begin{tabular}{|l} 
지표 2-1. 협력 기관에 역량 강화 교육을 제공한 \\
실적 닫성도 - 혁력 기관을 대상으로 역 \\
량 강화 교육 확동을 실시한 봉사단원 \\
1인당 협력 기관(또는 유관 기관) 관계자 \\
교윰 목표(1회 이상 교육을 받은 관계자 \\
수)에 대한 달성도 \\
· 측정산식: 가중치, 관련 활동 실시한 봉사단원 \\
수, 봉사단원 교육 제공 실적 및 목표치를 고려해
\end{tabular} \\
\hline
\end{tabular}




\begin{tabular}{|c|c|c|}
\hline 측정 분야 & 피스코 지표 및 산식 & WFK 지표 및 산식 \\
\hline & & 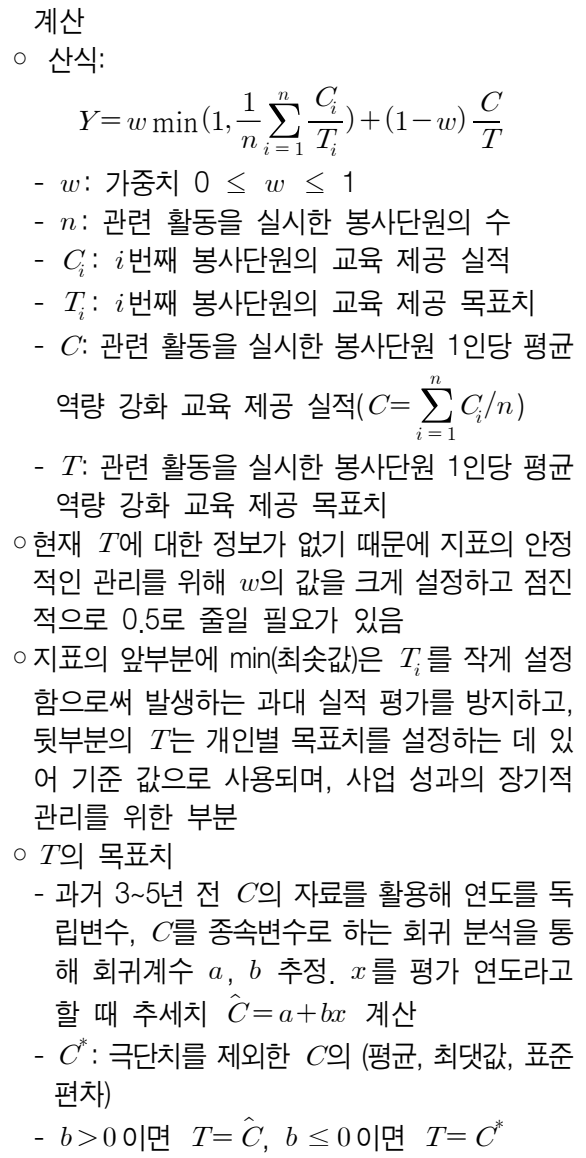 \\
\hline $\begin{array}{l}\text { 언어 습득 } \\
\text { 향상 }\end{array}$ & $\begin{array}{l}\text { 8.1: 언어 습득 향상 - 활동 종료 전 언어 테스 } \\
\text { 트에서 '고급' 및 '그 이상' 수준인 단원 비 } \\
\text { 율을 2018년까지 } 70 \% \text { 로 증대 } \\
\text { · 측정산식 : 활동 종료 시점에서 외국어능 } \\
\text { 력테스트(인터뷰)를 받은 봉사단원 중 '고 } \\
\text { 급' 또는 '최고급' 레벨을 통과한 단원 비 } \\
\text { 율 }\end{array}$ & $\begin{array}{l}\text { 지표 5-1. 봉사단 외국어 능력 향상도 - 봉사단원의 } \\
\text { 전기(前期) 대비 외국어 능력 향상 정도 } \\
\text { (봉사단원 전체 평균)를 측정 } \\
\text { - 측정산식: 외국어능력평가에 참여한 봉사단원 } \\
\text { 수, 전기 및 당기 등급 배점을 고려해 계산 } \\
Y=\frac{1}{n} \sum_{i=1}^{n}\left(T_{i}-C_{i}\right) \\
-n: \text { 전기-당기 외국어능력평가에 참여한 봉사단 } \\
\text { 원의 수 } \\
-C_{i}: i \text { 번째 봉사단원의 전기 등급 배점 } \\
-T_{i}: i \text { 번째 봉사단원의 당기 등급 배점 }\end{array}$ \\
\hline
\end{tabular}

출처: 한국국제협력단 (2017a), 홍문숙 외 (2017), Peace corps (2016) 내용을 저자가 재구성

위 <표 22>에서 볼 수 있듯, 피스코는 지표 자체가 간단명료하고 구체적이기 때문에(예: 활동 종료 전 언어테스트에서 ‘고급’ 및 '그 이상' 수준인 단원 비율을 2018년까지 70\%로 증대) 실무적으로 실현 및 관리가 용이하다. 반면, $\mathrm{WFK}$ 는 지표(안)의 구체성에 보완이 필요한 것으 
로 보인다(예: 봉사단원의 전기 대비 외국어 능력 향상 정도). 뿐만 아니라 피스코는 앞 장에서 거론한 바와 같이 지표의 설정 및 데이터 수집에 있어서도 근거와 품질을 명확히 하고 있다. 그러나 WFK가 제시(안)하는 측정산식은(예: $Y=w \min \left(1, \frac{1}{n} \sum_{i=1}^{n} \frac{C_{i}}{T_{i}}\right)+(1-w) \frac{C}{T}$ ) 피스코의 측정산식에 비해 다소 난해할 수도 있기에, 실무선에서 이해하고 측정을 지속하려면 재검토가 필요할 수도 있겠다.

따라서 WFK 성과를 장기적으로 모니터링하고 관리하기 위해서는 일반 직원이 아닌 전문가 만이 쉽게 이해할 수 있는 측정산식보다는 피스코와 같이 측정이 용이한 지표와 측정산식의 수립이 시급하다.

그러므로 $\mathrm{WFK}$ 중장기 성과 측정과 관리에 용이한 지표 및 측정 가능한 산식을 수립하기 위해서는 첫째, 본고에서 논한 타국 사례를 참고해 WFK 사업에 벤치마킹이 가능한 지표 pool 선정과 측정산식을 검토·연구하고, 둘째, 시범 데이터 수집 및 시범조사를 통해 벤치마킹이 가능한 지표 및 측정산식을 $\mathrm{WFK}$ 사업에 실제로 적용 및 조정하고, 셋째, 새롭게 정비된 지표와 산식을 WFK 사업에 점진적 적용 및 확산 등의 단계적 작업이 견고하고 논리적으로 수행되어야 하는 시점이라고 할 수 있다. 


\section{참고 문헌}

구영은-최경화·손성경. 2016. "WFK 중장기 전략 수립을 위한 수원국 중심의 해외봉사단

성과 요소 분석.”『국제개발협력』 2016-3호: 109-44.

구영은·최경화. 2017. "월드프렌즈코리아(WFK) 중장기 전략 수립을 위한 해외봉사 성

과측정 동향 분석."『국제개발협력』 2017-1호: 79-177.

이태주·박근혜·김헌·고은경·이순열·강하니·오연주·이선주·천유진·추빛나. 2016. 『KOICA

해외봉사단사업 종합평가 최종 보고서』. 서울: (사)글로벌발전연구원.

주성수·조영호·이란희·김이경. 2016. 『해외봉사단 효과성 증진을 위한 봉사단 분야별,

직종별 추진 전략』. 서울: 한양대학교 제 3 섹터연구소.

한국국제협력단. 2016a. 『2015 월드프렌즈코리아 통합 만족도조사 결과 보고서』. 성남:

한국국제협력단.

2016b. “2016년도 월드프렌즈코리아 봉사단원 만족도조사 <최종 보

고>”(내부 자료). 성남: 한국국제협력단.

2017a. "WFK 중기 성과 체계 및 추진 전략(2018 2022)" (내부 자료).

성남: 한국국제협력단.

2017b. “월드프렌즈코리아 사업의 이해”(내부 자료). 성남: 한국국제협

력단.

홍문숙·김헌·이순열·이선주·남종민·추빛나·이희철. 2016. 『월드프렌즈사업 성과관리

지표개발 연구』. 서울: (사)글로벌발전연구원.

홍문숙·김헌·이태주·여인권·김동욱·이순열·남종민. 2017. 『월드프렌즈코리아(WFK)

성과관리지표 고도화 및 통합 성과관리 시스템 구축』(내부 자료). 서울: (사)글로벌

발전연구원.

DFAT. 2014. "Evaluation of the Australian Volunteers for International

Development (AVID) program.” Canberra: Office of Development

Effectiveness (ODE), Australian Government Department of Foreign

Affairs and Trade (DFAT).

DFID. 2013. "Evaluation of the International Citizen Service." London.

Department for International Development (DFAT).

ICS. 2014. "ICS Annual Review." London: Voluntary Service Overseas (VSO). Peace Corps. 2016a. "Peace Corps Strategic Plan 2014-2018 Annual Performance 
Plan 2016.” Washington, DC: Peace Corps. 2016b. “Agency Financial Report.” Washington, D.C.: Peace Corps.

\section{[인터넷]}

피스코(Peace Corps) 홈페이지: https://pclive.peacecorps.gov (접속일: 2017.03.21.) 영국해외시민봉사단(International Citizens Service, ICS) 홈페이지: https://www.volunteerics.org (접속일: 2017.11.15.) 